\title{
PLOS Medicine
}

\section{Prevalence of IgG antibodies against SARS-CoV-2 among the general population and healthcare workers in India, June-July 2021 \\ --Manuscript Draft--}

\begin{tabular}{|c|c|}
\hline Manuscript Number: & PMEDICINE-D-21-03454R1 \\
\hline Full Title: & $\begin{array}{l}\text { Prevalence of IgG antibodies against SARS-CoV-2 among the general population and } \\
\text { healthcare workers in India, June-July } 2021\end{array}$ \\
\hline Article Type: & Research Article \\
\hline
\end{tabular}

Additional Information:

Question Response

\section{Financial Disclosure}

MVM received the funding from Indian Council of Medical Research, New Delhi. The funders were involved in study design, and the decision to publish and preparation of

Enter a financial disclosure statement that the manuscript. describes the sources of funding for the work included in this submission. Review 
the submission guidelines for detailed requirements. View published research articles from PLOS Medicine for specific examples.

This statement is required for submission and will appear in the published article if the submission is accepted. Please make sure it is accurate.

\section{Unfunded studies}

Enter: The author(s) received no specific funding for this work.

\section{Funded studies}

Enter a statement with the following details:

- Initials of the authors who received each award

- Grant numbers awarded to each author

- The full name of each funder

- URL of each funder website

- Did the sponsors or funders play any role in the study design, data collection and analysis, decision to publish, or preparation of the manuscript?

- NO - Include this sentence at the end of your statement: The funders had no role in study design, data collection and analysis, decision to publish, or preparation of the manuscript.

- YES - Specify the role(s) played.

* typeset

\section{Competing Interests}

The authors have declared that no competing interests exist.

Use the instructions below to enter a competing interest statement for this submission. On behalf of all authors, disclose any competing interests that could be perceived to bias this work-acknowledging all financial support and any other relevant financial or nonfinancial competing interests.

This statement will appear in the published article if the submission is accepted. Please make sure it is accurate. View published research articles from PLOS Medicine for specific 


$$
\text { examples. }
$$

NO authors have competing interests

Enter: The authors have declared that no competing interests exist.

\section{Authors with competing interests}

Enter competing interest details beginning with this statement:

I have read the journal's policy and the authors of this manuscript have the following competing interests: [insert competing interests here]

* typeset

This statement is required for submission and will appear in the published article if the submission is accepted. Please make sure it is accurate and that any funding sources listed in your Funding Information later in the submission form are also declared in your Financial Disclosure statement.

\section{Ethics Statement}

You must include an Ethics Statement in the Methods section of your manuscript if your study involved:

- Human participants

- Human specimens or tissue

- Vertebrate animals or cephalopods

- Vertebrate embryos or tissues

- Field research

\section{Not including a statement when required will delay the review process.}

General guidance is provided below.

Please consult the guidelines on human subjects research and animal research for 


\section{detailed instructions. \\ Format for specific study types \\ Human Subject Research (involving human participants and/or tissue) \\ - Give the name of the institutional review board or ethics committee that approved the study \\ - Include the approval number and/or a statement indicating approval of this research \\ - Indicate the form of consent obtained (written/oral) or the reason that consent was not obtained (e.g. the data were analyzed anonymously) \\ Animal Research (involving vertebrate \\ animals, embryos or tissues) \\ - Provide the name of the Institutional Animal Care and Use Committee (IACUC) or other relevant ethics board that reviewed the study protocol, and indicate whether they approved this research or granted a formal waiver of ethical approval \\ - Include an approval number if one was obtained \\ - If the study involved non-human primates, add additional details about animal welfare and steps taken to ameliorate suffering}

\section{Field Research}

Include the following details if this study involves the collection of plant, animal, or other materials from a natural setting:

- Field permit number

- Name of the institution or relevant body that granted permission

Please check the box to confirm your understanding of this policy, then read and agree to one of the statements.

Please respond:

as follow-up to "Ethics Statement
My study requires an ethics statement. I confirm I have included my statement in the Methods section of my uploaded manuscript file. 
You must include an Ethics Statement in the Methods section of your manuscript if your study involved:

- Human participants

- Human specimens or tissue

- Vertebrate animals or cephalopods

- Vertebrate embryos or tissues

- Field research

Not including a statement when required will delay the review process.

General guidance is provided below.

Please consult the guidelines on human subjects research and animal research for detailed instructions. 


\section{Format for specific study types}

Human Subject Research (involving human participants and/or tissue)

- Give the name of the institutional review board or ethics committee that approved the study

- Include the approval number and/or a statement indicating approval of this research

- Indicate the form of consent obtained (written/oral) or the reason that consent was not obtained (e.g. the data were analyzed anonymously)

\section{Animal Research (involving vertebrate}

\section{animals, embryos or tissues)}

- Provide the name of the Institutional Animal Care and Use Committee (IACUC) or other relevant ethics board that reviewed the study protocol, and indicate whether they approved this research or granted a formal waiver of ethical approval

- Include an approval number if one was obtained

- If the study involved non-human primates, add additional details about animal welfare and steps taken to ameliorate suffering

\section{Field Research}

Include the following details if this study involves the collection of plant, animal, or other materials from a natural setting:

- Field permit number

- Name of the institution or relevant body that granted permission

Please check the box to confirm your understanding of this policy, then read and agree to one of the statements. "

\section{Data Availability}

Yes - all data are fully available without restriction

Authors are required to make all data underlying the findings described fully available, without restriction, and from the time of publication. PLOS allows rare exceptions to address legal and ethical concerns. See the PLOS Data Policy and 
FAQ for detailed information.

A Data Availability Statement describing where the data can be found is required at submission. Your answers to this question constitute the Data Availability Statement and will be published in the article, if accepted.

Important: Stating 'data available on request from the author' is not sufficient. If your data are only available upon request, select 'No' for the first question and explain your exceptional situation in the text box.

Do the authors confirm that all data underlying the findings described in their manuscript are fully available without restriction?

Describe where the data may be found in All relevant data are within the manuscript and its Supporting Information files. full sentences. If you are copying our sample text, replace any instances of $X X X$ with the appropriate details.

- If the data are held or will be held in a public repository, include URLs, accession numbers or DOls. If this information will only be available after acceptance, indicate this by ticking the box below. For example: All XXX files are available from the $X X X$ database (accession number(s) $X X X, X X X$.).

- If the data are all contained within the manuscript and/or Supporting Information files, enter the following: All relevant data are within the manuscript and its Supporting Information files.

- If neither of these applies but you are able to provide details of access elsewhere, with or without limitations, please do so. For example:

Data cannot be shared publicly because of [XXX]. Data are available from the XXX Institutional Data Access / Ethics Committee (contact via $X X X)$ for 


researchers who meet the criteria for
access to confidential data.
The data underlying the results
presented in the study are available
from (include the name of the third party
and contact information or URL).
- This text is appropriate if the data are
owned by a third party and authors do
not have permission to share the data.
* typeset
Additional data availability information:




\section{Prevalence of IgG antibodies against SARS-CoV-2 among the general population and healthcare workers in India, June-July 2021}

Manoj V Murhekar ${ }^{1}$, Tarun Bhatnagar ${ }^{1}$, Jeromie Wesley Vivian Thangaraj ${ }^{1}, \mathrm{~V}$ Saravanakumar ${ }^{1}$, Muthusamy Santhosh Kumar ${ }^{1}$, Sriram Selvaraju ${ }^{2}$, Kiran Rade ${ }^{3}$, CP Girish Kumar ${ }^{1}$, R Sabarinathan ${ }^{1}$, Alka Turuk ${ }^{4}$, Nivethitha N Krishnan², Aby Robinson², Nivetha Srinivasan ${ }^{2}$, Smita Asthana ${ }^{5 *}$, Rakesh Balachandar6*, Sampada Dipak Bangar $^{7 *}$, Avi Kumar Bansal8*, Jyothi Bhat9*, Vishal Chopra10*, Dasarathi Das ${ }^{11 *}$, Alok Kumar Deb12*, Kangjam Rekha Devi13*, Gaurav Raj Dwivedi14*, S Muhammad Salim Khan ${ }^{15 *}$, M Sunil Kumar16*, Avula Laxmaiah17*, Major Madhukar18*, Amarendra Mahapatra11*, Chethana Rangaraju19*, Jyotirmayee Turuk ${ }^{11 *}$, Suresh Yadav20*, P K Anand ${ }^{20 \dagger}$, Rushikesh Andhalkar ${ }^{2}$, Nimmathota Arlappa ${ }^{17} \dagger$, Khalid Bashir ${ }^{15} \dagger$, Dinesh Kumar Bharadwaj ${ }^{17} \dagger$, Pravin Bharti ${ }^{\dagger}$, Debdutta Bhattacharya ${ }^{11} \dagger$, Sthita Pragnya Behera ${ }^{14} \dagger$, Ashrafjit S Chahal ${ }^{10} \dagger$, Debjit Chakraborty ${ }^{12} \dagger$, Anshuman Chaudhury ${ }^{2} \dagger$, Hirawati Deval ${ }^{14} \dagger$, Sarang Dhatrak ${ }^{6} \dagger$, Vikas Dhikav ${ }^{20} \dagger$, Rakesh Dayal ${ }^{21} \dagger$, Prathiksha Giridharan ${ }^{\dagger}$, Inaamul $\mathrm{Haq}^{15} \uparrow$, Babu Jagjeevan ${ }^{17} \dagger$, Agam Jain ${ }^{22} \uparrow$, Arshad Kalliath ${ }^{16} \uparrow$, Srikanta Kanungo ${ }^{11} \dagger$, T Karunakaran ${ }^{1} \dagger$, Jaya Singh Kshatri11 $†$, Niraj Kumar ${ }^{14} \dagger$, Vijay Kumar $^{5} \dagger$, VG Vinoth Kumar ${ }^{\dagger}$, G G J Naga Lakshmi ${ }^{23} \dagger$, Ganesh Mehta ${ }^{8}$, Anindya Mitra $^{21} \dagger$, K Nagbhushanam ${ }^{2} \dagger$, A R Nirmala ${ }^{24} \dagger$, Subrata Kumar Palo11 $†$, Ganta Venkata Prasad $^{23} \dagger$, Uday Kumar Pucha17†, Mariya Amin Qurieshi15 $\dagger$, Vikas Sabaharwal22†, Seema Sahay ${ }^{\dagger}$, Ramesh Kumar Sangwan ${ }^{20} \dagger$, Rochak Saxena ${ }^{25} \dagger$, Krithikaa Sekar ${ }^{2} \dagger$, Vijay Kumar Shukla ${ }^{25} \dagger$, Hari Bhan Singh ${ }^{8}$, Prashant Kumar Singh ${ }^{5} \dagger$, Pushpendra Singh ${ }^{9} \uparrow$, Rajeev Singh ${ }^{14} \uparrow$, Mahendra Thakor ${ }^{20 \dagger}$, Dantuluri Sheethal Varma ${ }^{23} \dagger$, Ankit Viramgami6 $†$, Pradeep A Menon²†, Rajiv Yadav9*, Surabhi Yadav², Manjula Singh4, Amit Chakrabarti6\#, Aparup Das9\#, Shanta Dutta12\#, Rajni Kant"14\#, A M Khan"\#, Kanwar Narain13\#, Somashekar Narasimhaiah ${ }^{19 \#, ~ C h a n d r a s e k a r a n ~ P a d m a p r i y a d a r s h i n i 2 \#, ~}$ Krishna Pandey ${ }^{18 \#, ~ S a n g h a m i t r a ~ P a t i 11 \#, ~ H e m a l a t h a ~ R a j k u m a r ~}{ }^{17 \#, ~ T ~ R a m e s h ~}{ }^{23 \#, ~ A r u n ~}$ Kumar Sharma20\#, YK Sharma ${ }^{25 \#, ~ S h a l i n i ~ S i n g h 5 \#, ~ S a m i r a n ~ P a n d a ~}{ }^{4}$, D C S Reddy ${ }^{26,}$ Balram Bhargava ${ }^{4}$ on behalf of ICMR serosurveillance group

${ }^{1}$ ICMR National Institute of Epidemiology, Chennai, Tamil Nadu

2 ICMR National Institute for Research in Tuberculosis, Chennai, Tamil Nadu

3WHO Country Office for India, New Delhi

4 Indian Council of Medical Research, New Delhi

5 ICMR- National Institute of Cancer Prevention \& Research, NOIDA, Uttar Pradesh

6 ICMR-National Institute of Occupational Health, Ahmedabad, Gujarat

7 ICMR-National AIDS Research Institute, Pune, Maharashtra

8 ICMR-National JALMA Institute for Leprosy \& Other Mycobacterial Diseases, Agra, Uttar Pradesh

9ICMR-National Institute of Research in Tribal Health, Jabalpur, Madhya Pradesh

10 State TB Training and Demonstration Centre, Patiala, Punjab

11 ICMR- Regional Medical Research Centre, Bhubaneswar, Odisha

12 ICMR- National Institute of Cholera and Enteric Diseases, Kolkata, West Bengal

13ICMR- Regional Medical Research Centre, N.E. Region, Dibrugarh, Assam

${ }^{14}$ ICMR- Regional Medical Research Centre, Gorakhpur, Uttar Pradesh

${ }^{15}$ Govt Medical College Srinagar, Srinagar, Jammu and Kashmir

${ }^{16}$ State TB Training \& Demonstration Centre, Thiruvananthapuram, Kerala

${ }_{17}$ ICMR - National Institute of Nutrition, Hyderabad, Telangana

18ICMR-Rajendra Memorial Research Institute of Medical Sciences, Patna, Bihar

19 National Tuberculosis Institute, Bangalore, Karnataka 
20ICMR, National Institute for Implementation Research on Non-Communicable Diseases, Jodhpur, Rajasthan

21 State TB Training and Demonstration Centre, Ranchi, Jharkhand

22 NTEP Consultant, Uttarakhand

23 State TB Office, Hyderabad, Andhra Pradesh

${ }^{24}$ Lady Willingdon State TB Centre, Bengaluru, Karnataka

25 State TB Training and Demonstration Centre, Raipur, Chhattisgarh

26 Independent consultant, Lucknow, Uttar Pradesh

*Authors in alphabetical order, contributed equally

tAuthors in alphabetical order, contributed equally

\#Authors in alphabetical order, contributed equally

Correspondence to:

Dr Manoj V Murhekar,

ICMR National Institute of Epidemiology,

Chennai 600077, India

mmurhekar@nieicmr.org.in

ICMR sero-surveillance group

Epidemiology and Surveillance Working Group: Tanu Anand, Giridhara R Babu, Himanshu Chauhan, Tanzin Dikid, Raman R Gangakhedkar, Shashi Kant, Sanket Kulkarni, J P Muliyil, Ravindra Mohan Pandey, Swarup Sarkar, Naman Shah, Aakash Shrivastava, Sujeet K Singh, Sanjay Zodpey

Laboratory and data management team: K Aparna, K Arul, PR Asish, M Chellakumar, D Chokkalingam, R Gunasekaran, Anusha Hindupur, S Kalaivani, K Kalaiyarasi, C Kanagasivam, N N Karthick, G Kiruthika, S Manickam, M Purushothaman, S Sarathkumar, M P Sarath Kumar, E Michaelraj, Josephine Pradhan, E B Arun Prasath, Sudha Rani, Amanda Rozario, R Sivakumar, P Gnana Soundari, K Sujeetha, P Tamilselvi, G Veeravel, Arya Vinod. 


\section{Abstract}

Background: India began COVID-19 vaccination in January 2021 initially targeting the healthcare and frontline workers. The vaccination strategy was expanded in a phased manner and currently covers all individuals aged 18 years and above. India witnessed a severe second wave of COVID-19 during March and June 2021. We did the fourth nationwide serosurvey to estimate prevalence of SARS-CoV-2 antibodies in the general population aged $>=6$ years and health care workers (HCWs).

Methods and findings: We did a cross-sectional study between 14 June and 6 July 2021 in 700 clusters in the same 70 districts across 21 states/Union Territory. From each district, a minimum of 400 individuals aged $>=6$ years from general population and 100 $\mathrm{HCW}$ from the district public health facilities were included. The serum samples were tested for the presence of IgG antibodies against S1-RBD and nucleocapsid protein of SARS-CoV-2 using chemiluminescence immunoassay. We estimated the weighted and test adjusted seroprevalence of IgG antibodies against S1-RBD and/or nucleocapsid protein along with $95 \% \mathrm{Cl}$.

Of the 28,975 sera tested, the weighted and test adjusted prevalence of IgG antibodies against S1-RBD and/or nucleocapsid protein among the general population aged $>=6$ years was $67.6 \%$ (95\% Cl: 66.4 - 68.7). The seroprevalence increased with age and was not different in rural and urban areas. Compared to unvaccinated adults $(62.3 \%, 95 \% \mathrm{Cl}$ : 60.9 - 63.7), seroprevalence was significantly higher among individuals who received one (81.0\%, 95\% Cl: 79.6 - 82.3) and two doses (89.8\%, 95\% Cl: 88.4 - 91.1). The seroprevalence of IgG antibodies among 7,252 health care workers was $85.2 \%$ (95\% Cl: 83.5 - 86.7).

Our study has certain limitations. First, our serosurvey was designed to estimate the seroprevalence at the national level and it might not have captured variation in the seroprevalence within the states and districts. Second, approximately $19 \%$ of eligible individuals were not included in the survey, as they were not available in the household at the time of survey or they refused to participate. This could introduce a selection bias, if this non-response was not at random.

Conclusions: Nearly two of the three individuals aged $\geq 6$ years from the general population and $85 \%$ HCWs had antibodies against SARS- CoV-2 by June 2020 in India. As one third of the population is still seronegative, it is necessary to accelerate the coverage of COVID-19 vaccination among adults. COVID-19 cases in India have been declining since May 2021. However, continued surveillance for COVID-19 cases is necessary to detect upsurge of COVID-19 cases early. The ongoing genomic surveillance for SARS-CoV2 also needs to be strengthened to inform about the emergence of newer variants including their ability to circumvent immunity conferred by the natural infection as well as vaccination. Finally, high seroprevalence observed in the general population should not be a reason for complacency. It is essential to continue adherence to nonpharmaceutical interventions, such as avoiding gatherings, ensuring social distancing, and using face masks in public places. 


\section{Introduction}

With more than 30 million cases and 0.48 million deaths as on 5 July 2021, India has the second largest number of COVID-19 cases reported globally. ${ }^{1}$ India witnessed a severe second wave of COVID-19 since March 2021, affecting all states of India. ${ }^{2}$ Repeated cross sectional serosurveys in the same geographical location are useful to monitor the trends of seroprevalence over time and provide evidence for the public health decision making to plan the response. ${ }^{3}$ Serial serosurveys conducted in 70 districts spread across 21 Indian states/Union Territory prior to introduction of COVID-19 vaccination indicated that the seroprevalence increased from $0.73 \%$ (95\% Cl: 0.34-1.13) during May-June 2020, to 6.6\% (95\% Cl 5.8-7.4) during Sept-October 2020 and 24.1 (95\%Cl: $23.0 \%$ to $25.3 \%$ ) during December 2020 -January $2021 .{ }^{4-6}$ About $25 \%$ healthcare workers working in peripheral health facilities in these 70 districts had evidence of IgG antibodies against SARS-CoV-2 during December 2020 - January $2021 .{ }^{6}$ The earlier nationwide serosurveys in the general population were conducted among individuals aged 10 years and above while the information about the seroprevalence among children below 10 years is not known.

Since January 16, 2021 India initiated COVID-19 vaccination with BBV152 (Covaxin; Bharat Biotech International Ltd, Hyderabad) and ChAdOx1 nCoV-19 vaccine (Covishield, Serum Institute of India, Pune) for the healthcare and frontline workers. The vaccination strategy was expanded in a phased manner to cover individuals above 60 years old and above 45 years old with specified comorbidities (phase-2, March 1, 2021), all individuals aged 45 years and above (phase 3, April 1, 2021) and all individuals aged 18 years and above (phase 4 , May 1,2021$){ }^{7}$

In this context, we conducted fourth round of nationwide serosurvey to estimate the agespecific prevalence of SARS-CoV-2 antibodies in the general population and health care workers.

\section{Methods}

Study design and participants:

We conducted a cross-sectional survey between 14 June and 6 July 2021 in the same 70 districts spread across 21 Indian states/Union Territory where three rounds of serosurveys were conducted ${ }^{4-6}$. We selected 10 clusters (Wards in urban areas and villages in rural areas) from each district using population proportion to size method. The survey teams selected four random starting points within each of the selected cluster. Starting from a random starting point, the teams visited consecutive households and listed all household members aged 6 years and above and who were permanently residing in the area. Eligible individuals present in the household were invited to participate in the survey. From each random location, at least 10 consenting individuals (1 aged 6-9 years, 2 aged 10-17 years and 7 aged 18 years and above) were enrolled in the survey. Enrolment of a minimum number of individuals in each age group ensured that the overall distribution of the sampled population was comparable to the age structure of the population in India. ${ }^{8}$ Thus, a minimum of 40 individuals from each cluster and 400 individuals from each district were enrolled. We enrolled at least 100 healthcare workers from each of the 70 districts selected for the general population 
survey. We consecutively enrolled the willing HCWs (Doctors, nurses, para medical staff and lab staff) working in the district headquarters hospital of the selected study district

\section{Procedures}

We interviewed eligible consenting participants to collect information about demographic details, history of symptoms suggestive of COVID-19 (eg, fever, cough, shortness of breath, sore throat, new loss of taste or smell, fatigue) since 1 January 2021, COVID-19 testing and COVID-19 vaccination. Three $\mathrm{mL}$ of venous blood was collected from each participant, and serum samples were transported to ICMR National Institute of Epidemiology, Chennai under cold chain.

We tested the serum samples for the presence of IgG antibodies against S1-RBD (ADVIA Centaur XP/XPT, Siemens Healthineers, Munich, Germany) and nucleocapsid (Abbott Architect, Abbott Park, IL, USA) protein of SARS-CoV-2 using chemiluminescence immunoassay, as per the manufacturer's instructions. The Siemens assay is a quantitative antibody assay with analytical measuring interval of $0.50-150.0$; samples with an index value of $\geq 1$ are considered as reactive. The assay has sensitivity of $96.4 \%$ (95\% Cl: 92.7-98.5\%) after 21 days of PCR confirmation of SARS-CoV-2 infection and specificity of $99.0 \%$ (95\% Cl: 99.6-99.9). ${ }^{9}$ The Abbott assay for IgG antibodies against nucleocapsid protein is a qualitative assay and has a sensitivity of $100.0 \%$ and specificity of $99.6 \%$ after 14 days of PCR confirmation. ${ }^{10}$ As a part of quality control, $10 \%$ of positive serum samples and an equal number of negative serum samples were re-tested using the same assay.

We also separately estimated the performance of the two assays by testing 100 prepandemic sera samples collected as a part of acute fever surveillance during 2016 and 140 samples from laboratory confirmed COVID-19 patients collected over 30-240 days after confirmation of RT-PCR. ${ }^{11}$ We estimated the specificity of $99.0 \%$ (95\% Cl: 94.6 100.0\%) and sensitivity of $80.0 \%$ (95\% Cl: $72.4-86.3 \%)$ for S1-RBD and specificity of 100\% (95\% Cl: 96.4 - 100) and sensitivity of 61.4\% (95\% Cl: 52.8 - 69.5) for nucleocapsid assay in detecting historical infection (supplementary material).

Data analysis

The characteristics of study participants was described as proportions. Individuals whose sera were positive for IgG antibodies against S1-RBD and/or nucleocapsid proteins were considered as seropositive. We calculated design weights as the product of inverse of sampling fraction for the selection of districts and selection of clusters within each district. We estimated the weighted seroprevalence of IgG antibodies along with $95 \% \mathrm{Cl}$, using a random-effects model to account for cluster sampling. The weighted seroprevalence was further adjusted for the joint sensitivity and specificity of the two assays using the sensitivities and specificities estimated by the manufacturer. ${ }^{12} \mathrm{We}$ also conducted a sensitivity analysis to estimate the seroprevalence by using the lowest sensitivity and specificity of the two assays estimated through the external validation studies as well as by considering the sensitivity and specificity estimated during in-house validation (supplementary material). We also estimated the seroprevalence by selected demographic and COVID-19-related characteristics of the study participants.

To estimate the total number of individuals infected with SARS-CoV-2 at the national level, we applied the weighted seroprevalence of IgG antibodies against SARS-CoV-2 among children aged 6-17 years to the total population of children aged 6-17 years. To 
estimate the total number of infections among individuals aged $\geq 18$ years, we considered two scenarios: First, we applied the weighted seroprevalence among unvaccinated individuals aged 18 years and above to the total population of unvaccinated individuals aged $>=18$ years. Second, we applied the weighted seroprevalence among unvaccinated to the total population above 18 years. The infection to case ratio (ICR) was calculated by dividing the estimated number of SARSCoV-2 infection with the cumulative number of COVID-19 cases reported in India 1 and 2 weeks before the median survey date (23 June 2020) assuming lgG antibodies start appearing between 5 and 15 days post infection. ${ }^{13}$

Protection of human participants: A written informed consent was taken from individuals aged $\geq 18$ years. For children aged between 7 and 17 years, we obtained assent and written consent from their parents or guardians, while parental consent was obtained for children aged 6 years. The Institutional Human Ethics Committee of the ICMR National Institute of Epidemiology, Chennai approved the study protocol.

\section{Results}

\section{Seroprevalence among general population}

The survey teams visited 16, 074 households from 700 clusters in 70 Indian districts. Of the 35, 561 individuals aged $\geq 6$ years residing in these households, 28, 975 (81.5\%) consented to participated in the survey (Fig 1).

Of the 28,975 individuals who participated in the survey, $2892(10 \%)$ were aged 6-9 years, 5798 (20\%) were aged 10-17 years and 20,285 (70\%) were aged $\geq 18$ years. $15,160(52.3 \%)$ participants were females and 21,794 (75.2\%) resided in rural areas (Table 1). 4372 (15.1\%) of the 28, 956 individuals reported history of COVID-19 testing in the past, of whom $782(17.9 \%)$ reported a positive test result. Of the 20,268 adult participants, $5038(24.8 \%)$ and 2631 (13.0\%) reported receipt of one and two doses of COVID-19 vaccines respectively, while the remaining 12,599 (62.2\%) were unvaccinated. Most $(n=6945,90.6 \%)$ had received Covishield vaccine (Table 1). The median interval between the receipt of the first dose and date of sample collection was 36 days (IQR: 14 - 68 ) and 60 days (IQR: 34 - 98) between the receipt of second dose and sample collection.

Of the 28,975 sera tested, 11, 289 (38.9\%) had IgG antibodies against nucleocapsid protein, 18388 (63.5\%) had antibodies against S1-RBD and $19336(66.7 \%)$ had antibodies against nucleocapsid and/or S1-RBD. The weighted prevalence of IgG antibodies either against S1-RBD and/or nucleocapsid protein was 67.6\% (95\% Cl: 66.4 - 68.7) after adjusting for assay characteristics (Table 2). The overall seropositivity in states ranged between 44.3\% (Kerala) and 80.0\% (Madhya Pradesh) (Supplementary material). The seroprevalence was heterogenous among the 70 districts, ranging between 40.5\% (Ernakulam, Kerala) and 86.8\% (Buxar, Bihar) (Supplementary material). Compared to December 2020, the seropositivity among unvaccinated individuals aged 10 years and above during June 2021 had increased by $1.2-1.9$ folds in 21 (30.0\%) districts, 2 - 3 folds in 31 (44.3\%) districts and >3 folds in $18(25.7 \%)$ districts (Supplementary material).

The seroprevalence showed a rising trend with age. Among children aged 6-9 years and 10-17 years, respectively 57.2\% (95\% Cl: 55.0 - 59.4) and 61.6\% (95\% Cl: 59.8 - 63.3) 
had antibodies against SARS-CoV-2. The seroprevalence among adults ranged between $66.7 \%$ (95\% Cl: 65.3 - 68.0) in 18-44 years and $77.6 \%$ (95\% Cl: 76.1 - 79.0) in 45-60 years. The seroprevalence was not different in rural, urban non-slum and urban slum areas. Among the 487 unvaccinated individuals with history of laboratory confirmed COVID-19 infection, 88.0\% (95\% Cl: 83.0-91.8) had detectable antibodies against SARSCoV-2 (Table 3).

Compared to unvaccinated adults, the seroprevalence was significantly higher among individuals who received one $(81.0 \%, 95 \% \mathrm{Cl}: 79.6-82.3, p=0.001)$ and two doses (89.8, 95\% Cl: 88.4 - 91.1, $p=0.001)$ of COVID-19 vaccines. This increase was observed in all age-groups, both sexes and all localities among the individuals in general population as well as healthcare workers (Table 4 and supplementary material). The seroprevalence was higher among individuals who received Covishield (85.2\%, 83.8 $86.5)$ as compared to those who received Covaxin $(80.2 \%, 76.1-83.8) \quad(p=0.004)$. (Table 3). After one dose, the seroprevalence was $80.8 \%(95 \% \mathrm{Cl}: 75.7-85.0)$ for Covaxin and $82.0 \%$ (95\% Cl: 80.3-86.6) among Covishield recipients. Individuals who received two doses had higher seroprevalence, ranging between $86.3 \%$ to $90.3 \%$ for Covaxin and Covishield respectively (Table 4). A similar pattern was observed among healthcare workers (Supplementary material).

The weighted prevalence of IgG antibodies against nucleocapsid protein was 38.3 (95\% $\mathrm{Cl}$ : 37.0 - 39.5) (Table 2). The anti-N seropositivity was not different by age, gender and area of residence (Supplementary material). Also, around one third of the individuals vaccinated with Covishield had anti-N IgG antibodies.

Using the sensitivities and specificities estimated from the inhouse validation and external studies, the overall seroprevalence of IgG antibodies against SARS-CoV-2 was 73.2\% (95\% Cl: 71.9 - 74.4) and 68.0\% (95\% Cl: 66.8 - 69.1) respectively.

We estimated $642,751,546$ to $807,395,611$ SARS-CoV-2 infections in India by mid-June 2021. With 2,90,88,245 and 2,96,32,302 cases reported by 9 June and 16 June 2021 respectively, the infections per reported COVID-19 case ranged between 21.7 and 27.2 (supplementary material).

\section{Seroprevalence among healthcare workers}

We enrolled 7,252 healthcare workers from the district public hospitals of the 70 districts selected for general population survey. Most $(n=5133,70.8 \%) \mathrm{HCW}$ were aged between 18-44 years and 51.3\% ( $n=3722)$ were females. Of the $4892(67.4 \%)$ HCWs who reported history of COVID-19 testing, 1354 (27.7\%) had a positive test result. 89.5\% $(n=6493)$ had reported history of COVID-19 vaccination, while the remaining were unvaccinated (Table 1).

Of the 7252 healthcare workers, 6186 (85.3\%) had antibodies against nucleocapsid and/or S1-RBD with the seroprevalence of 85.2 (83.5 - 86.7) after adjusting for assay characteristics (Table 2). The seroprevalence was not different by age groups and sex (Table 3). The seroprevalence was higher among HCWs who received one $(87.7 \%, 95 \%$ $\mathrm{Cl}: 85.0$ - 89.9) and two doses (88.6\%, 95\% Cl: 87.1 - 90.1) of COVID-19 vaccines as compared to unvaccinated individuals $(64.8 \%, 95 \% \mathrm{Cl}: 60.1-69.2)$. 


\section{Discussion}

The results from the fourth nationwide serosurvey indicate that about two-third of India's population aged 6 years and above had antibodies against SARS-CoV-2 by June 2021. The seroprevalence increased with age. The seroprevalence was comparable in rural, urban non-slum and urban slum areas. Majority of HCWs working in the district level health facilities were positive for IgG antibodies. These findings have important implications on the future trajectory of COVID-19 in India.

The overall prevalence of IgG antibodies against SARS-CoV-2 increased from $24.1 \%$ by December 2020 to $67.6 \%$ by June 2021 . This increase in the seroprevalence could be on account of natural infection as well as COVID-19 vaccination. The seroprevalence among unvaccinated adults in June 2021 was $62.3 \%$ as against $24.3 \%$ in December 2020. This finding indicates that a large proportion of the increase in the seroprevalence was on account of the natural infection during the second wave of COVID-19 in India during March and June 2021. Around 38\% of the individuals had anti-N antibodies indicating recent transmission of SARS-CoV-2. ${ }^{14}$ During this period more than 20 million COVID-19 cases were reported from India, ${ }^{2}$ with delta variant being a predominant circulating variant of concern (VOC). ${ }^{15}$

The increase in seroprevalence was observed in all age groups, including children aged 10-17 years (2.2 fold) (supplementary material). Children aged 6-9 years were not covered during the previous serosurveys. During June 2021, about $60 \%$ of children had evidence of antibodies against SARS-CoV-2. The findings of high seropositivity among children observed in our study are consistent with a recent study conducted during March and June 2021 among children from five sites in India . ${ }^{16}$ Among the 700 individuals aged $<18$ years surveyed in this study, $55.7 \%$ were seropositive.

Earlier serosurveys have indicated higher seroprevalence among urban slums and urban non-slum areas than rural areas. This gradient in the seroprevalence seems to have faded by June 2021, with a comparable seroprevalence in the rural and urban areas. Higher seroprevalence in rural areas observed in our survey indicate that the infection in the second wave was widespread in rural areas.

The results of the Phase 2 trials reported that $98.4 \%(95 \% \mathrm{Cl}: 95.3-99.7)$ individuals vaccinated with BBV152 (Covaxin) ${ }^{17}$ and $100 \%$ (95\% Cl: 97.4 - 100.0) individuals vaccinated with Covishield ${ }^{18}$ seroconverted 56 days after the second dose. An observational multi-centric study among health care workers in India reported a seropositivity of $98.1 \%$ among Covishield and $80 \%$ among Covaxin recipients. ${ }^{19}$ In another study of antibody responses in a cohort of 45,965 adults from the general population of the United Kingdom who received either ChAdOx1 or the BNT162b2 SARSCoV-2 vaccines, authors estimated that about $6 \%$ of the participants were 'low responders' ${ }^{20}$ In our serosurvey, about $10-14 \%$ of the vaccinees were found to be seronegative even after the receipt of two doses of COVID-19 vaccine. The proportion of seronegative individuals did not change when we considered the optimal interval between the second dose and sample collection of more than 7 days. Because of crosssectional nature of the study, we are not able to comment if the seronegativity among the fully vaccinated individuals was on account of lower antibody response or decline in antibodies. Moreover, the possibility of misclassification of vaccination status cannot be ruled out as the information about vaccination was based on recall. 
The number of infections per reported case between December 2020 (27.1- 26.7) and June 2021 (21.7 - 27.8) has not changed. This reflects on sustained testing (around 210 million tests conducted during this period) of both symptomatic and asymptomatic eligible individuals. ${ }^{6}$

Seroprevalence studies can help predict the future course of the pandemic. ${ }^{3}$ Prior to the second wave in India, about $75 \%$ of the population was seronegative. ${ }^{6}$ The serosurvey findings indicate that about one third of the general population in India did not have detectable antibodies against SARS-CoV-2 by June 2021. It is therefore possible that more COVID-19 cases are likely to occur in coming months, especially in areas where the proportion of people without detectable antibodies is higher. The available evidence indicates that immunity acquired through natural infection can last up to one year. ${ }^{21}$ IgG antibodies against the RBD of the spike protein shows a high correlation to virus neutralization titres indicating the neutralising nature of the antibodies. ${ }^{22,23}$ Studies also indicate that re-infections among previously infected individuals are less frequent. ${ }^{24}$ It is thus reasonable to expect that the future surge of cases in India would be lower than the second wave. However, the immunity acquired through natural infection as well as vaccination is expected to wane over time. Although S1-RBD are considered to have the neutralising effect, protective titre among the seropositive individuals is not known. Further, COVID-19 cases could rapidly increase after emergence of immune escape variants. ${ }^{25}$ It is therefore necessary to continue monitoring the emergence of VOCs.

Our study has certain limitations. First, our serosurvey was designed to estimate the seroprevalence at the national level and it might not have captured variation in the seroprevalence within the states and districts. Second, approximately 19\% of eligible individuals were not included in the survey, as they were not available in the household at the time of survey or they refused to participate. This could introduce a selection bias, if this non-response was not at random. Third, IgG antibodies against SARS-CoV-2 wane over time. ${ }^{14,26}$ In our study, the seropositivity to S1-RBD and nucleocapsid protein among unvaccinated individuals with laboratory confirmed COVID-19 RT-PCR was $82.4 \%$ and $63.4 \%$ respectively. Hence, the observed seroprevalence might be under-estimate of the actual seroprevalence in the population.

In conclusion, our serosurvey findings indicate that nearly two of the three individuals aged $\geq 6$ years from the general population and $85 \% \mathrm{HCWs}$ had antibodies against SARSCoV-2 by June 2020 in India. As one third of the population is still seronegative, it is necessary to accelerate the coverage of COVID-19 vaccination among adults. COVID-19 cases in India have been declining since May 2021. However, continued surveillance for COVID-19 cases is necessary to detect upsurge of COVID-19 cases early. The ongoing genomic surveillance for SARS-CoV-2 also needs to be strengthened to inform about the emergence of newer variants including their ability to circumvent immunity conferred by the natural infection as well as vaccination. Finally, high seroprevalence observed in the general population should not be a reason for complacency. It is essential to continue adherence to non-pharmaceutical interventions, such as avoiding gatherings, ensuring social distancing, and using face masks in public places. 


\section{Authors contributions}

MVM, TB, JWVT, MSaK, KR, DCSR, SP and BB designed the study. SSe, AT, NNK, AR, NS MVM, MSaK, JWVT did project management. MSK, JWVT, RSa, SA, RB, SDB, AKB, JB, VC, DD, AKD, KRD, GRD, SMSK, MSUK, AL, MM, AMa, CR, JT, SY, PKA, RA, NA, KB, DKB, PB, DB, SPB, ASC, DC, AC, HD, SD, VD, RD, PG, IH, BJ, AJ, AK,SK, JSK, NK, VK, VGVK, GGJN, GM, KN, ARN, SKP, AKP, GVP, UKP, MAQ, VSab, SSa, RKS, RS, KS, VKS, HBS, PKS, PS, RSi, MT,DSV,AV, PAM, RY, SY, MS, AC, AD, SD, RK, AMK, KN, SN, CP, KP, SaP, HR, TR, AKS, YKS and ShS coordinated the blood sample and data collection. CPGK with the support of TK coordinated the laboratory processing and testing of samples. VS, JWVT, MVM, RSa and MSaK performed data analysis. MVM, TB, JWVT, MSaK, KR, SP, DCSR and BB performed data interpretation. MVM, TB, VS, JWVT, RSa and MSaK accessed and verified the data. MVM, TB, MSaK and JWVT wrote the first draft of the manuscript. All authors approved the final version of the manuscript.

\section{Declaration of interests}

We declare no competing interests.

\section{Data sharing}

A subset of the key anonymised individual participant data collected during the study, along with a data dictionary, is available upon request to the corresponding author, after approval of a proposal with a signed data access agreement. 


\section{References}

1World Health Organization. WHO Coronavirus (COVID-19) Dashboard. 2021; published online May 7. https://covid19.who.int/table (accessed July 28, 2021).

2Government of India. COVID-19 Dashboard. 2021; published online May 7. https://www.mygov.in/covid-19.

3 World Health Organization. Population-based age-stratified seroepidemiological investigation protocol for coronavirus 2019 (COVID-19) infection, 26 May 2020. Geneva: World Health Organization, 2020 https://apps.who.int/iris/handle/10665/332188.

4Murhekar MV, Bhatnagar T, Selvaraju S, et al. Prevalence of SARS-CoV-2 infection in India: Findings from the national serosurvey, May-June 2020. Indian J Med Res 2020; 152: 48-60.

5Murhekar MV, Bhatnagar T, Selvaraju S, et al. SARS-CoV-2 antibody seroprevalence in India, August-September, 2020: findings from the second nationwide household serosurvey. The Lancet Global Health 2021; 9: e257-66.

6 Murhekar MV, Bhatnagar T, Thangaraj JWV, et al. SARS-CoV-2 seroprevalence among the general population and healthcare workers in India, December 2020-January 2021. International Journal of Infectious Diseases 2021; 108: 145-55.

7 Ministry of Health and Family Welfare. COVID-19 Vaccine FAQs. https://www.mohfw.gov.in/covid_vaccination/vaccination/faqs.html (accessed July 29, 2021).

8Census of India Website: Office of the Registrar General \& Census Commissioner, India. C-13 Single year age returns by residence and sex.

https://censusindia.gov.in/2011census/C-series/C-13.html (accessed July 29, 2021).

9Siemens Healthineers. SARS-CoV-2 IgG Assay. https://www.siemenshealthineers.com/laboratory-diagnostics/assays-by-diseases-conditions/infectiousdisease-assays/cov2g-assay (accessed July 29, 2021).

10 Health C for D and R. EUA Authorized Serology Test Performance. FDA 2021; published online May 25. https://www.fda.gov/medical-devices/coronavirus-disease2019-covid-19-emergency-use-authorizations-medical-devices/eua-authorized-serologytest-performance (accessed July 29, 2021).

11 Thangaraj JWV, Kumar MS, Kumar CG, et al. Persistence of humoral immune response to SARS-CoV-2 up to 7 months post-infection: Cross-sectional study, South India, 2020-21. J Infect 2021; : S0163-4453(21)00268-1.

12 Sempos CT, Tian L. Adjusting Coronavirus Prevalence Estimates for Laboratory Test Kit Error. American Journal of Epidemiology 2021; 190: 109-15.

13 Sette A, Crotty S. Adaptive immunity to SARS-CoV-2 and COVID-19. Cell 2021; 184: 861-80.

14 lyer AS, Jones FK, Nodoushani A, et al. Persistence and decay of human antibody responses to the receptor binding domain of SARS-CoV-2 spike protein in COVID-19 patients. Sci Immunol 2020; 5. DOI:10.1126/sciimmunol.abe0367.

15 Dhar MS, Marwal R, Radhakrishnan VS, et al. Genomic characterization and Epidemiology of an emerging SARS-CoV-2 variant in Delhi, India. medRxiv 2021; : 2021.06.02.21258076.

16 Misra P, Kant S, Guleria R, Rai SK, Aiims WUS study team of. Serological prevalence of SARS-CoV-2 antibody among children and young age (between age 2-17 years) group in India: An interim result from a large multi-centric population-based seroepidemiological study. medRxiv 2021; : 2021.06.15.21258880.

17 Ella R, Reddy S, Jogdand H, et al. Safety and immunogenicity of an inactivated SARS-CoV-2 vaccine, BBV152: interim results from a double-blind, randomised, 
multicentre, phase 2 trial, and 3-month follow-up of a double-blind, randomised phase 1 trial. The Lancet Infectious Diseases 2021; 21: 950-61.

18 Marathe S. Covishield-ChAdOx1 nCoV-19 Corona Virus Vaccine Insert, Domestic New 02012021.cdr. ; : 2.

19 Kumar Singh A, Phatak SR, Singh R, et al. Antibody Response after Second-dose of ChAdOx1-nCOV (Covishield ${ }^{\mathrm{TM}}$ ) and BBV-152 (Covaxin ${ }^{\mathrm{TM}}$ ) among Health Care Workers in India: Final Results of Cross-sectional Coronavirus Vaccine-induced Antibody Titre (COVAT) study. Allergy and Immunology, 2021 DOI:10.1101/2021.06.02.21258242.

20 Wei J, Stoesser N, Matthews PC, et al. Antibody responses to SARS-CoV-2 vaccines in 45,965 adults from the general population of the United Kingdom. Nat Microbiol 2021; : 1-10.

21 Turner JS, Kim W, Kalaidina E, et al. SARS-CoV-2 infection induces long-lived bone marrow plasma cells in humans. Nature 2021; 595: 421-5.

22 Wajnberg A, Amanat F, Firpo A, et al. Robust neutralizing antibodies to SARS-CoV2 infection persist for months. Science 2020; 370: 1227-30.

23 Irsara C, Egger AE, Prokop W, et al. Clinical validation of the Siemens quantitative SARS-CoV-2 spike IgG assay (sCOVG) reveals improved sensitivity and a good correlation with virus neutralization titers. Clinical Chemistry and Laboratory Medicine (CCLM) 2021; 59: 1453-62.

24 Hall VJ, Foulkes S, Charlett A, et al. SARS-CoV-2 infection rates of antibodypositive compared with antibody-negative health-care workers in England: a large, multicentre, prospective cohort study (SIREN). The Lancet 2021; 397: 1459-69.

25 Prévost J, Finzi A. The great escape? SARS-CoV-2 variants evading neutralizing responses. Cell Host Microbe 2021; 29: 322-4.

26 Bolotin S, Tran V, Osman S, et al. SARS-CoV-2 Seroprevalence Survey Estimates Are Affected by Anti-Nucleocapsid Antibody Decline. J Infect Dis 2021; 223: 1334-8. 


\section{Acknowledgements}

The authors acknowledge the field supervision and support provided by WHO India; the Ministry of Health and Family Welfare, Government of India; state and district health officials; and primary healthcare staff in the planning and conduct of the serosurvey. The authors thank the following team members from different Indian states.

\section{Assam}

Doirai Basumatary, Liladhar Boro, Jumanjyoti Sarmah, Anjan Saikia, Anu Chouhan, Dhurbajyoti Pathak, Nagen Sarmah, Tapan Hazarika, Nandeswar Hazarika, Arup Kr. Deka, Joydhon Timung, Suprotin Khatoniar, Upashna Bora, Dondodhar Gogoi, Thomas Langthasa, Thaneswar Teron, Bijoybhusan Deka, Sibsankar Chakaraboty, Pranjal Nath Ranjit Das, Bibek Saikia, Ritwik Dutta, Dipti Kangkana Kachari, Amir Sohail Khan, Mrinal Nagtey, Rimpi Konwar, Jasuda Chetia, Gunin Mili, Boidujya Rai Gogoi, Bidya Pegu, Ananta Borah, Gamuk Kuttum, Ranjali Doley, Agastin Kerketta, Santanu kakoty, Pullab Das, Prahlad Das, Paramananda Upadhaya, Krishna Khadka, Pankaj Phukan, Pranjal Das, Samir Ranjan Borah, Rituraj Buragohain, Tapan Kalita, Mrinmoy Gogoi, Amit Kr. Ray, Diganta Karmakar and Mahanta Gogoi

\section{Bihar}

Naveen Kumar Mandal, Kumar Gautam, Sanjeev Gupta, Ujjwal Prakash, Sahdeo Mandal, Prakash Ranjan, Saurav Kumar, Santosh Kumar, Rohit Kumar, Sashi Bhusan Awasthi, Mritunjay Kumar Pandey, Paras Kumar, Kumar Rakesh Mandal, Satish Kumar Thakur, Subhash Kumar, Manohar Kumar, Amit Lakra, Ashish Kumar, Binod Kumar, Rishikesh Kumar, Prateek Raushan, Vikas Kumar, Saurabh Krishna, Baidyanath Roy, Alok Kumar, Santosh Singh, Sakaldeep Kumar, Ajeet Kumar, Aaditya Panday, Umesh Kumar, Dhirendra Kumar, Amar Kant Singh, Sanjeet Kumar, Bhoop Dhakar, Vikash Kumar Roy, Kundan Kunal, Vikash Kumar, Kumar Abhijeet, Amrendra Kumar, Vikram Kumar Chaudhary, Mohammad Arif, Raneeta Singh, Madhu Kumari, Roushan Kumar, Parul Priya, Pooja Kumari, Manoj Kumar, B.P. Subramanya, Ujjwal Prasad Sinha, Rajeev Chandra Kumar, Ashish Tigga, Sanjay Kumar Singh, Geetika Shankar, Anand Gautam, Susheel Gautam, Rajendra Kumar, Adarsh Varghese, Anisur Rehman Bhuiyan and Kunnal Kuvalekar.

\section{Chhattisgarh}

Archana Nagwanshi, Sunil Kumar Pankaj, Irshad Khan, Chetan Ravishankar Raut, Kunjbihari Patel, Chandra Kishore Thakre, Pekhan Kumar Sahu, Nand Kumar Modi, Nand Kumar Sahu, Bhoopendra Thakur, Awadh Baghel, Hemant Bawthande, Dev Kumar Sahu, Rajesh Kumar Soni, Devdas Joshi and Vokesh Yadu

\section{Gujarat}

Dinkar Raval, SK Makwana, A.M. Kadri, Harsh Bakshi, Pranav Patel, Arthur Mcwan, Anand Santoke, Pankaj Nimawat, Shabbir Ali Dedhrotiya, YK Jani, Jitendra Patel, Hasmukh Parmar, Hardik Nakshiwala, Vaidehi Gohil, Jaydip Oza, Vikas Kokare, Mihir Rupani, Ankit Sheth, Parulben Patel, Jigneshbhai Tadvi, Priyank Gandhi, Piyushbhai Parasar, Vinodbhai Valvi, Jagdishbhai Padvi, Dhawal Patel, Divyaben Zala, Mayurbhai Vasava, Manmitbhai Solanki, Darshnaben Patel, Chetnaben Chaudhari, Aartiben Rathva, 
Riyaben Mistry, Nikiben Bhau, Jyotsnaben Bariya, Tejasbhai Patel, Kartikbhai Prajapati, Babita Roy, Pareshbhai Parmar, Manojbhai Bhagora, Pareshbhai Patel, Hemantbhai Kalasva, Shardaben Vankar, Divya Patel, Ravisinh Chauhan, Nimisha Patel, Misha Patel, Harsha Sadat, Puja Patel, Girish Shah, Partapsinh Taviyad, Raginiben Gosai, Krutikaben Rana, Imtiyazbhai Shaikh, Madhuben Mahera, Bhavikaben Patel, Prakashakumar Patel, Sangitaben Patel, Geetaben Patel, Pratapbhai Pagi, Bharatbhai Rana, Jinalben Patel, Archanaben Pandavi, Dilipbhai Baria, Ishavar Sinh Rathod, Sharmishtha Patel, Sunitaben Solanki, Bhavesh Vaghela, Moinuddin Mansuri, Nitesh Rathore, Purvi Nayak, Hardeep Khair, Rajendra Acharya, Vijyaben Amin, Nirmal Prajapati, V.J. Pargi, Asmitaben Kharadi, Rajubhai Patel, Komalben, Hemangini Baria, Meenaben Bamaniya, Shantaben Prajapati, Rameshbhai Patel, Imran Mansuri, Yashvantbhai Nayak, K.K. Parmar, Rahul Siroi, Krunal Darji, Mahavir Solanki, Shivani Joshi and Mahesh Gavit.

\section{Jammu and Kashmir}

Haseena Mir, Syed Arshad Rafiq, Iram Sabah, Misbah Ferooz Kawoosa , Abdul Aziz Lone, Ishtiyaq Ahmad Sumji, Mehvish Afzal Khan, Shaista Ismail, Anjum Asma, Shifana Ayoub, Javed Ahmad Bhat, Shafin Ashraf wani, Asima Nazir, Mohd. Ashraf Bhat, Irfana Gani, Neelofar Akram, Riyaz A Wani, Manzoor A Magray, Gulban Fayaz, Parsa Shafi, Aasim Abubakar, Aymen Deeba, Aasim Maqbool, Firdous Mushtaq Khan, Mir Waleed, Inam Zahoor, Nimrat ul Ain Banday, Kaisar Hamid Malla, Saika Parvaiz, Wajahat Nazir Shazia Akhtar, Nazir Ahmed Bhat, Mushtaq Ahmad Bhat, Jehangi Ahmad Bhat, Naseeb Singh Bali, Ferooz Ahmad, Altaf Ahmad, Abdul Rashid Dar, Farooq Ahmad Magray, Manzoor ahmad, Gh Mustafa Bhat, Feroz Ahmad Bhat.

\section{Jharkhand}

Asit Mansingh, Amiya Ranjan Mohanta, Anjan Kumar Bishoyee, Trilochan Bhoi, Matrujyoti Pattnaik, Santosh Kumar Sahoo, Rajesh Kumar Panda, Ashok Kumar Mahakud, Debashish Mishra, Partha Sarathi Patra, Dasrath Majhi, Santosh Kumar Behuria, Jeevan Kumar Mohanto, Biren Kumar Padhy, Chanan Kumar Majhi, Krushna Chandra Dalei, Soumya Ranjan Panda

\section{Karnataka}

Jawaid Akhtar, K V Thrilok Chandra, Arundathi Chandrashekar, Patil Om Prakash, Rameshchandra Reddy,N Udanesha, Sarika Jain Agrawal, H P Arundathi Das, Ranganath R, Vivekanand Reddy,Mahesh Kumar, Bilagumba Ramaiah Venkateshaiah, Prathibha Javare Gowda, Ambaraya Rudrawadi, Basavaraj Biradar, Anand PrakashK R Nischith, G Hamsaveni, Satish Ghatage, R S Sreedhar, Mishba Hani, Anil Talikoti, N T Nagraja, , Pranesh Katti, Ratnasheela, Qayyum, Sangamesh,Shridhar, Amrut, Sankar Gouda, Maruthi Kamble, Anitha Jadhav, Deepak Patil, Amaraya Rudrawadi, S K Ravikanti,G Abhay Kumar, Ratnakar Toran, Suresh Doddamani, Suresh Mekin ,Deepak Patil, Siddaramappa Patil, Avinash Khaske, Abdul Jabbar, Shashidhar Patanaik, Amaresh Kolur, Asha,Shobha Nagesh, Ramya R, Babu Mahendra, Kusuma S, Roopashree, Malathi Y S, Bharath,Latha, Sudha,Shivakumar, G, Srinivas, Sadiqulla Sharif, Jagadeesh, Dilip,Vijay, Mallikarjunappa, Kavitha, Sudha, Premasudha, Chandrashekhar Kambalimat, Girish, Jayashimha, Venkatesh, Ananda Prakash, Shree Harsha, Vijayalakshmi N, Somashekharayya S Hiremath, K Jaya Ganesh, H S Charan Raj Rao, T.N.Basavaraju, B.Sampath, T.G.Gangadharaiah, H T Mangalagowri, Nagaraja P C, Ravikumara M T, Srikantha Y G, Hariprashanth R, Praveen Pujar, Bheema Zakeer 
Hussain, Namewar Hanmanth, Kokila Manickam, Gowri K, Shadul Fakirsab Sayyad, Lal Kumar R, Ullera Ashoka, A N Sunil, Umar Farooque M Dalawai, Manjunatha M, Venkatesh A Millanatti, B.Dinesh Kumar, Narasimharaju N, Deepak, Sundara Murthi.R.

\section{Kerala}

Aravind Krishnan, Manoj M, Anumol Raju, Anupranam M P, Arima A R, Soniya Joseph, Shilna A, Vishnu Raj, Prakash Jaison V, Venoth V S, Gladson J, Ganga G S

\section{Maharashtra}

Ankita Dahiwade, Shabana Khan, Swati Salunkhe, Seema Nair, Shudhanshu Rane, Kanad Patil, Suresh Kumar, Savita Bahekar, Rakesh Gaikwad, Pravin Dandge, Namrata Hajari, Anil Rathod, Shaikh Shahrukh, Dinesh Jadhav, Pooja Pawara, Sonal Gawai, Priyanka Bawane, Vinod Pethkar, Dhiraj Panpatil, Ajit Buchude, Sourabh Tidake, Sagar Rokade, Bhuddhabhushan Bhadke, Kapil Khandagale, Chaitanya Deshmukh, Adinath Rokde, Suraj Rakhunde, Prathamesh Chavan, Pramod Jamale, Rahul Arke, Vivek Yengade, Tejas Phale, Amarkumar Ambade, N. Ramaswami, Satish Pawar, Archana Patil, Pradeep Awate, Jyoti Gurav, Abhijeet Raut, Deepak Mugalikar, Vipin Itankar, Rajendra Bhosale, Ravindra Jagtap, Abhijeet Chaudhari, Rajesh Deshmukh, Nagurao S. Chavan, Bhimashankar Jamadar, Nilkanth Bhosikar, Balaji Shinde, Suryankant Sable, Radhakrishna Pawar, Sunil Pokhrna, Sandip Sangle, Sanjay Salunkhe, Milind Pore, Balasaheb Nagargoje, Shankararo Deshmukh, Sandip Bharaswadkar, Aniruddha Kadu, Rajiv Kumar, Hemant Kharnare, Suhasini Kadhe, Avinash Jadhav, Chetan Khade, Amol Gaikwad, Virendra Wankhede, Prakash Nandapurkar, Jyoti Salve

\section{Madhya Pradesh}

M.P. Sharma, Shivendra Mishra, Mahavir Khandelwal, Sunita Parmar, Devendra Gothwal, Manish Sharma, Seema Jaiswal, B.K. Tiwari, Arvind Verma, Ajay Goel, Purushottam Patel Ganesh Damor, , Bhagwansingh Patil, Ramswaroop Uikey, , Akanksha Kushram, Sandip Sharma, Himmat Singh, Yogendra Mourya, Prahlad Soni, Pushpendra Rajput, Priyanka Birha, Monu Sen, Rekha Prajapati, Priyanka Singore, Lipi Jain, Ashok Solanki, Kalpana Patel, Bhagat Dhurvey, Rahul Choubey, Pehal Singh Tekam, Rajendra Mehra, Ramcharit Rakesh Tiwari, Prathinesh Parouha, Rahul Belawi, Yagendra Kumar, Amit Raikwar and Twinkle Dewaker

\section{Odisha}

AsitMansingh, Shakti Ranjan Barik, Siba Prasad Mallik, Prashant Majhi, Deepak Sahoo, ParthaSarathi Patra, A.K. Bishoyee, Hitesh Kumar Jain, Indurani Sagar, Santosh Kumar Sahoo, Rajesh Panda, Santosh Kumar Beuria, Sidhartha Kar, Soumya Panda, K. Sahu, MatrujyotiPattnaik, Dasarath Majhi, Biren Kumar Padhi, Padmamohan Pradhan and Arun Padhi.

\section{Rajasthan}

Rajkumar Kalunda, Rajneesh Kumar, Anil Purohit, Chet Ram Meena, Pankaj Kumar, Trilok Kumar, Bhanwar Manohar, Mohit Yadav, Jograj Singh, Ayub Khan, Ram Naresh Jani 


\section{Tamil Nadu}

Y. John Arokyadoss, P. Kumaravel, A. Vasudevan, Magesh Kumar, J. Chitra, Santhana Kumar, Sadham Hussain, Kuppusamy Chandrabalu, Chandra Kumar, Selvam Suresh, Nandha Kumar, Dhanagopal Rajmohan, G, Thanappan Selvendran, Suryanarayanan Santhosh, Annadurai Arjun, N. Kumaravel, Vinoth

\section{Telangana}

R. Ananthan, Dudekula Anwar Basha, Blessy Prabhu Priyanka Salavadi, ChandraKumar Dolla, S. Devindra, Gargi Meur, Indrapal.I. Meshram, Paras Sharma, P. Raghavendra, Santosh Kumar Banjara, J. Ch. Sairam, Srinivas Rao, F. Sylvia, , MV Surekha, N.Samarasimha Reddy, Tata Aruna Kumari, V.Aruna, Ch. Anitha, N. Anjaiah, G.Bhavani, Ch. Bujji, Hrusikesh Panda, G. Hari Babu, N. Jhansi, S.V.J.Mohan Naidu, G.Neeraja, B.V. Nancharamma, D.Narasimhulu, P.Nagulu, Sk.Nasarvali, S.P.V. Prasad, B. Praveen, Ch.Pallavi, R.Raghunadh Babu, R.Rajyalaxmi, G.Venkat Raji Reddy, D.Rani, J.Raju Naik, V.Ravi, Ch.Sai Babu, G.L.Stephen, K. Sree Ramakrishna, PV. Sunu, P. Sreenu,

D.Swaroopa, E. Sheela, M.Srinivas, P.Sathaiah, M.Suresh, P.Sriram, K.Sridhar, B. Srikant, R.Satyanarayanan, V.Sai Santosh, G.Tulasi, T.Usha Rani, K.Venkata Ramana, P. Venkatamma, D.Vasundhara and G. Vijaya Lakshmi.

\section{Uttar Pradesh- West}

Prabhat kumar, Dilip Singh, Naresh Dhakar, Rahul Kumar, Akash Yadav, Arpita Chaturvedi, Swati Singh, Brijesh Maurya, Manisha Dhakar, Narendra Singh Yadav, Sheena Singh, Renu Kanwar, Sonu Yadav, Rahul Yadav, Mewa kumar, Himalaya Kumar, Raju Deen Dayal, Balijeet Sodhi, Rajesh Jain, Shivanka Gaur, Akhil Tondon, Deepak Ohari, Saubhagya Prakash, Amit kumar, Haridutt Nemi

\section{Uttar Pradesh- Central/Himachal Pradesh \& Uttarakhand}

Dechen Yangdol, Upendra Singh, Amit Yadav, Mohit Tiwari, Gopal Prasad, Sapna Yadav, Basudev Singh, Deepak Babu, Rahul Kumar, Chakrapani Katara, Chandra Pratap Singh, Simran Kaur Bhojwani, Manish Kumar, P. Vedival, Ranjan Karmakar, Vivek Kumar, Rahul Gond, Prabhat Kumar, Hariom Kushwah, Gani Aftridi, Nistha Verma, Veer Vishal, Rakesh Sharma, Uday Singh, Saurav Yadav, Navneet Rajput, Satya Prakash, Sunny Sharma, Santosh Kushwah, Akhalesh Yadav, Papai Das, Mahavir Singh Chaudhary, Prabha Shakya, Gulshan Sahu, Kumari Dipika, Sushil Chander, Manoj Sharma, Satyvrat Vaidya, Archana Srivastava, Shishir Puri, Vishal Agnihotri, Ashish Dixit, Ashutosh Kumar, Jairam Singh, Lalit Kumar, Tanmay Kakkar, Misaam Abbas, Akhileshwar Singh, Ashish Nautiyal, Manoj Kumar, Sushil Kumar, Shailendra Barthwal, Prakash Tapriyal, Subodh Kumar, Sanjay Pandey, Namita Puri, Arti Behal, V.C Kala, Ghambir Taliyan, Gaurav Raturi, Rashi Ranjan Kukreti, Pankaj Juyal, Kuldeep Kumar, Ashok Kumar, Dhani Ram, Prem Kumar, Loknath Sharma, Suraj Mani, Raj Kumari, Jitendra Kumar, Kiran Chauhan, Prakash Tapriyal, Vineet Kumar Shukla, J.S. Rawat, Himanshu Sharma, Madhu Kumari, Rajesh Mourya, R.S. Yadav, Surinder Singh, Raju Kumavat, Sandeep Patil, Pradhumn Katara, Namrata Soni, Prashant Upadhyaya, Praveen Pachauri, Ajay Rawat, Sanjay Chopra, Jyoti Mishra, Mohammed Husain, Devi Lal

\section{Uttar Pradesh- East}


Amit Mohan Prasad, Shruti Pandey, Markandey Shahi, Amit S Bansal, Atul Kumar Singhal, Sushil Kumar, Radhey Shyam Kesari, Ajay Pratap Singh, Vinay Dange, Ghanshyam Singh, Shri Prakash Agrawal, Shyam Narayan Dubey, Birendra Panchal, Vishal Yadav, Mukesh Kumar Mishra, Ravi Shankar Singh, Kamlesh Sah, Sonal Rajput, Sushil Pal, Ravi Nishad, Rohit Baghel, Punit Kumar, Abhishek Kumar Mishra, Avdhesh Kumar, Anugunj Chaudhary, Pawan Kumar, Surabhi Kushwaha, Mohammed Afroz, Lal Chand, Nisha Yadav, Anil Kushwaha, Deepak Kumar, Vipul Kumar, Kiran Kumari, Akash Kushwaha, Vinod Kumar, Ram Poojan Yadav and Santosh Kumar.

\section{West Bengal}

Falguni Debnath, Agniva Majumder, Gargi Dutta Bhattacharyya, Subrata Biswas, Ajay Chakraborty, Jayesh Mehta, Bandita Sengupta, Abhijit Dey, Arup Chakrabortty, Subhendu Kumar Ray, Shourav Tarak, Subhadip Bhunia, Debasish Roy, Shyamal Soren, Jagannath Sarkar, Somnath Mukherjee, Prakash Chandra Mridha, Girish Chandra Bera, Bibhas Roy, Santanu Sahu, Atrayee Chakraborty, Rabiul Islam Gayen, Dilip Biswas, Samudra Sengupta, Barnaman Tudu, Tanmoy Kumar Ghosh, Ananya Biswas, Poulami Sen, Sonali Das, Tridib Das, Tarun Khatua, Paritosh Mondal, Saptarshi Bannerjee, Amit Baran Barat, Arindam Sarkar, Soumen Jana, Joyeeta Bhattacharyya, Medhavi Manish, Biswajit Namasharma, Chandan Ghosh, Debarati Chakraborty, Kunal Maiti, Milan Barman, Pintu Manik, Purnima Roy, Rajani Kurmi, Rocky Ansari, Sanglap Maity, Somobrota Naskar, Sourav Pradhan, Bishakha Pramanik, Dipannita Sardar, Sujit Kumar Shreshta, Arpita Das, Ujjal Maitra, Nawaid Ali, Chandan Ghosh, Susanta Bera, Sk. Monirul Jaman, Dev Kumar Dolai, Purnima Das, Wasim Reza, Shrikant Shankar Gawali and Rajesh Das. 
Figure: Participant enrolment

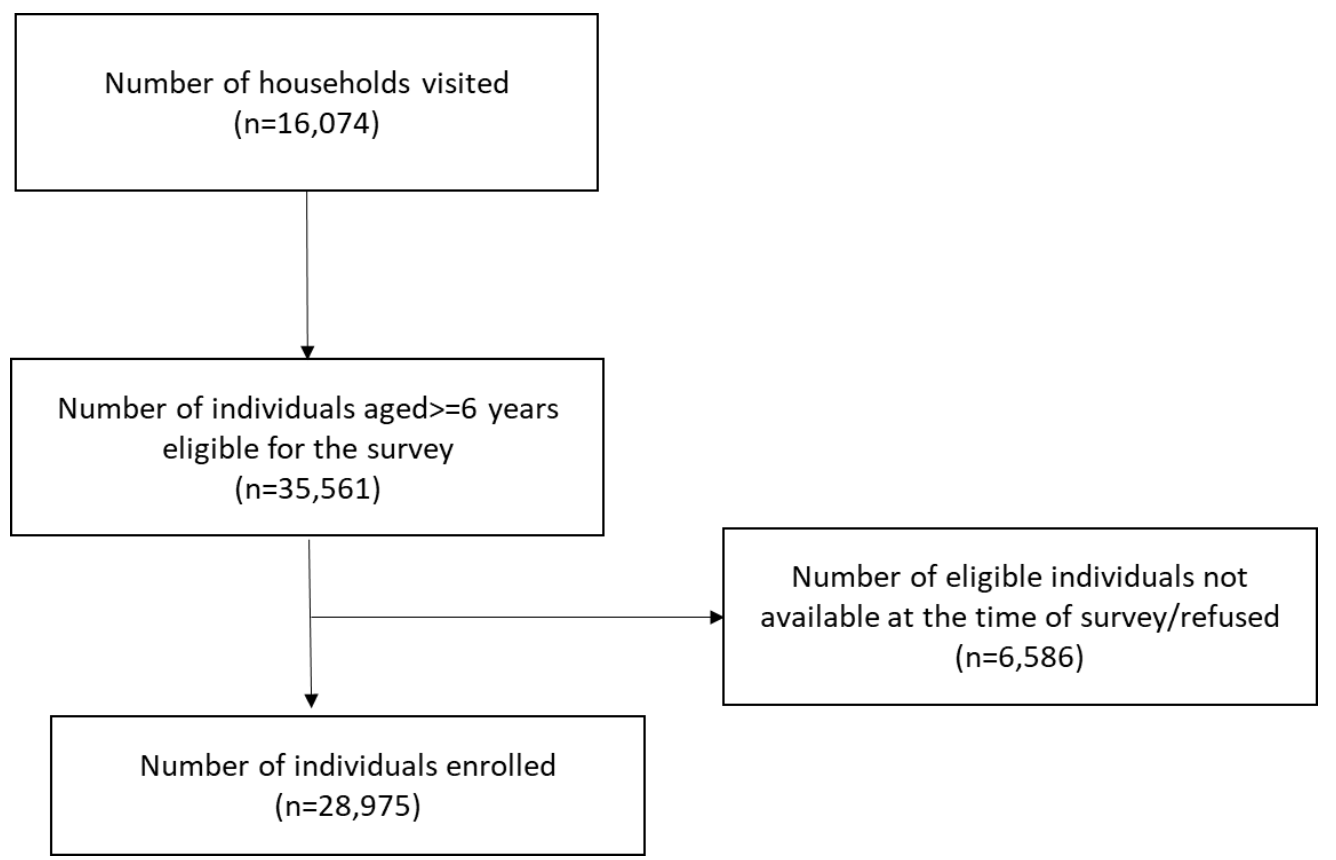


Table 1: Participant characteristics

\begin{tabular}{|c|c|c|}
\hline Characteristics & $\begin{array}{l}\text { General population } \\
\mathrm{n}(\%)\end{array}$ & $\begin{array}{l}\text { Healthcare } \\
\text { workers } \\
\mathrm{n}(\%)\end{array}$ \\
\hline Age (in years) & $n=28975$ & $n=7252$ \\
\hline $6-9$ & $2892(10.0)$ & - \\
\hline $10-17$ & $5798(20.0)$ & - \\
\hline $18-44$ & $12522(43.2)$ & $5133(70.8)$ \\
\hline $45-60$ & 5545 (19.1) & $1997(27.5)$ \\
\hline$>60$ & $2218(7.7)$ & $122(1.7)$ \\
\hline Sex & $\mathrm{n}=28975$ & $\mathrm{n}=7252$ \\
\hline Male & $13783(47.6)$ & $3523(48.6)$ \\
\hline Female & $15160(52.3)$ & $3722(51.3)$ \\
\hline Other & $32(0.1)$ & $7(0.1)$ \\
\hline Area of residence & $\mathrm{n}=28975$ & \\
\hline Rural & $21794(75.2)$ & - \\
\hline Urban non-slum & $5266(18.2)$ & - \\
\hline Urban slum & $1915(6.6)$ & \\
\hline COVID-19 related symptoms & $\mathrm{n}=28975$ & $\mathrm{n}=7252$ \\
\hline \multirow[t]{2}{*}{$\begin{array}{l}\text { History of COVID-19 symptoms since January } \\
2021\end{array}$} & $1748(6.0)$ & $925(12.8)$ \\
\hline & $\mathrm{n}=1729$ & $n=925$ \\
\hline Medical care sought for symptomatic cases & $574(33.2)$ & $558(60.3)$ \\
\hline \multirow[t]{2}{*}{ History of hospitalization } & $140(24.4)$ & $171(30.6)$ \\
\hline & $\mathrm{n}=28956$ & $\mathrm{n}=7252$ \\
\hline \multirow[t]{2}{*}{$\begin{array}{l}\text { History of contact with a known COVID-19 } \\
\text { case }\end{array}$} & $2129(7.3)$ & $4562(62.9)$ \\
\hline & $\mathrm{n}=\mathbf{2 8 9 5 6}$ & $n=7252$ \\
\hline Previously tested for COVID-19 & $4372(15.1)$ & $4892(67.4)$ \\
\hline Previous positive COVID-19 test & $782(17.9)$ & $1354(27.7)$ \\
\hline COVID-19 vaccination status among adults & $\mathrm{n}=\mathbf{2 0 2 6 8}$ & $\mathrm{n}=7252$ \\
\hline 0 dose & $12599(62.2)$ & $759(10.5)$ \\
\hline 1 dose & $5038(24.8)$ & $972(13.4)$ \\
\hline 2 doses & $2631(13.0)$ & $5521(76.1)$ \\
\hline Type of Vaccine & $\mathrm{n}=7669$ & $n=6493$ \\
\hline Covaxin & $587(7.7)$ & $498(7.7)$ \\
\hline Covishield & $6945(90.6)$ & $5973(92.0)$ \\
\hline Sputnik & $18(0.2)$ & $6(0.1)$ \\
\hline Don't know & $119(1.6)$ & $16(0.2)$ \\
\hline
\end{tabular}


Table 2: Seroprevalence (\%) of immunoglobulin G antibodies against severe acute respiratory syndrome coronavirus-2 infection, India, June-July 2021

\begin{tabular}{|c|c|c|c|c|c|c|}
\hline & \multicolumn{3}{|c|}{ General population aged $\geq 6$ years } & \multicolumn{3}{|c|}{ Healthcare workers } \\
\hline & Anti-N antibodies & $\begin{array}{c}\text { Anti-S1-RBD } \\
\text { antibodies }\end{array}$ & $\begin{array}{c}\text { Anti-N and/or } \\
\text { anti-S antibodies }\end{array}$ & Anti-N antibodies & $\begin{array}{c}\text { Anti-S1-RBD } \\
\text { antibodies }\end{array}$ & $\begin{array}{c}\text { Anti-N and/or } \\
\text { anti-S antibodies }\end{array}$ \\
\hline $\begin{array}{l}\text { Number of } \\
\text { individuals tested }\end{array}$ & 28975 & 28975 & 28975 & 7252 & 7252 & 7252 \\
\hline Number of positives & 11289 & 18388 & 19336 & 2305 & 6112 & 6186 \\
\hline $\begin{array}{l}\text { Unweighted } \\
\text { prevalence * (\%) } \\
95 \% \mathrm{Cl}\end{array}$ & 38.9 (37.9 - 40.1) & $63.5(62.3-64.6)$ & $66.7(65.6$ - 67.8) & $31.8(29.7-34.0)$ & $84.3(82.5$ - 85.9) & $85.3(83.6$ - 86.8) \\
\hline $\begin{array}{l}\text { Weighted } \\
\text { prevalence** (\%) } \\
95 \% \mathrm{Cl}\end{array}$ & $38.5(37.3-39.7)$ & $64.4(63.2-65.6)$ & $66.6(65.3$ - 67.9) & & & \\
\hline $\begin{array}{l}\text { Adjusted } \\
\text { prevalence*** (\%) } \\
95 \% \mathrm{Cl}\end{array}$ & $38.3(37.0$ - 39.5) & $66.8(65.5-68.0)$ & $67.6(66.4-68.7)$ & 31.5 (29.4 - 33.7) & $87.4(85.6$ - 89.1) & $85.2(83.5-86.7)$ \\
\hline
\end{tabular}

*Adjusted for clustering

$* *$ Weighted for design weights

$* * *$ Adjusted for test performance 
Table 3: Seroprevalence of IgG antibodies by selected characteristics, June-July 2021

\begin{tabular}{|c|c|c|c|c|c|c|}
\hline \multirow[t]{2}{*}{ Characteristics } & \multicolumn{3}{|c|}{ General population } & \multicolumn{3}{|c|}{ Healthcare workers } \\
\hline & $\begin{array}{l}\text { No. } \\
\text { tested }\end{array}$ & $\begin{array}{l}\text { No. positive } \\
\text { (anti-N and/or } \\
\text { anti-S1-RBD } \\
\text { antibodies) }\end{array}$ & $\begin{array}{l}\text { Weighted and test- } \\
\text { performance-adjusted } \\
\text { seroprevalence } \\
\%(95 \% \mathrm{Cl})\end{array}$ & $\begin{array}{l}\text { No. } \\
\text { tested }\end{array}$ & $\begin{array}{l}\text { No. positive } \\
\text { (anti-N and/or } \\
\text { anti-S1-RBD } \\
\text { antibodies) }\end{array}$ & $\begin{array}{l}\text { Test-performance- } \\
\text { adjusted } \\
\text { seroprevalence } \\
\%(95 \% \mathrm{Cl})\end{array}$ \\
\hline \multicolumn{7}{|l|}{ Age, years } \\
\hline $6-9$ & 2892 & 1635 & $57.2(55.0-59.4)$ & - & - & - \\
\hline $10-17$ & 5798 & 3584 & $61.6(59.8-63.3)$ & - & - & - \\
\hline $18-44$ & 12522 & 8245 & $66.7(65.3-68.0)$ & 5133 & 4401 & $86.5(84.9-88.0)$ \\
\hline $45-60$ & 5545 & 4217 & $77.6(76.1-79.0)$ & 1997 & 1686 & $85.1(83.0-87.1)$ \\
\hline$>60$ & 2218 & 1655 & $76.7(74.6-78.7)$ & 122 & 99 & $80.4(71.9-86.8)$ \\
\hline \multicolumn{7}{|l|}{ Sex } \\
\hline Male & 13783 & 9018 & $65.8(64.4-67.1)$ & 3523 & 3024 & $86.2(84.4-87.8)$ \\
\hline Female & 15160 & 10295 & $69.2(67.9-70.5)$ & 3722 & 3157 & $85.9(84.1-87.6)$ \\
\hline Other & 32 & 23 & $83.4(59.1-94.6)$ & 7 & 5 & $66.4(26.9-91.3)$ \\
\hline \multicolumn{7}{|l|}{ Area of residence } \\
\hline Rural & 21794 & 14398 & $66.7(65.4-68.1)$ & - & - & \\
\hline Urban non-slum & 5266 & 3587 & $69.1(66.6-71.6)$ & - & - & - \\
\hline Urban slum & 1915 & 1351 & $71.0(66.8-74.7)$ & - & - & - \\
\hline \multicolumn{7}{|c|}{ History of COVID-19 related symptoms since 1 Jan 2021} \\
\hline Yes & 1748 & 1262 & $76.8(74.4-79.0)$ & 925 & 838 & $85.2(83.6-86.8)$ \\
\hline No & 27227 & 18074 & $66.9(65.7-68.1)$ & 6327 & 5348 & $91.5(89.2-93.2)$ \\
\hline \multicolumn{7}{|l|}{ Previously tested for COVID-19 } \\
\hline Yes & 4372 & 3196 & $78.7(77.1-80.2)$ & 4892 & 4194 & $86.9(85.2-88.4)$ \\
\hline No & 24584 & 16127 & $65.6(64.4-66.9)$ & 2360 & 1992 & $84.2(81.9-86.3)$ \\
\hline \multicolumn{7}{|l|}{ Previous COVID-19 test result } \\
\hline $\begin{array}{l}\text { Reported positive for COVID- } \\
19\end{array}$ & 782 & 674 & $88.9(86.8$ - 90.8) & 1354 & 1275 & 94.8 (93.4 - 96.0) \\
\hline $\begin{array}{l}\text { Reported Negative for COVID- } \\
19\end{array}$ & 3419 & 2425 & $75.2(73.2-77.0)$ & 3395 & 2789 & $83.3(81.1$ - 85.3) \\
\hline
\end{tabular}




\begin{tabular}{|c|c|c|c|c|c|c|}
\hline Don't know & 171 & 97 & $71.1(59.2-80.5)$ & 143 & 130 & $90.1(80.6-95.2)$ \\
\hline \multicolumn{7}{|c|}{ COVID-19 vaccination status among adults } \\
\hline 0 dose & 12599 & 7758 & $62.3(60.9-63.7)$ & 759 & 507 & $64.8(60.1-69.2)$ \\
\hline 1 dose & 5038 & 4016 & $81.0(79.6-82.3)$ & 972 & 834 & $87.7(85.0-89.9)$ \\
\hline 2 doses & 2631 & 2331 & $89.8(88.4-91.1)$ & 5521 & 4845 & $88.6(87.1-90.1)$ \\
\hline \multicolumn{7}{|c|}{ Optimal interval between vaccination and blood sample collection } \\
\hline Less than 21 days of $1^{\text {st }}$ dose & 1711 & 1242 & $73.5(70.6$ - 76.2) & 191 & 151 & $78.0(70.7-83.9)$ \\
\hline 21 days after $1^{\text {st }}$ dose & 3327 & 2774 & $85.9(84.3-87.4)$ & 781 & 683 & $89.8(87.2-92.1)$ \\
\hline 7 days after $2^{\text {nd }}$ dose & 2630 & 2330 & $90.4(88.9-91.7)$ & 5513 & 4837 & $88.6(87.1-90.1)$ \\
\hline \multicolumn{7}{|l|}{ Vaccine type } \\
\hline Covaxin & 587 & 473 & $80.2(76.1-83.8)$ & 498 & 428 & $86.5(82.7-89.5)$ \\
\hline Covishield & 6945 & 5751 & $85.2(83.8-86.5)$ & 5973 & 5229 & $88.6(87.0-90.1)$ \\
\hline \multicolumn{7}{|c|}{ Previously positive for COVID-19 } \\
\hline 0 dose & 487 & 402 & $88.0(83.0-91.8)$ & 140 & 116 & $83.6(76.0-89.2)$ \\
\hline 1 dose & 145 & 134 & $95.0(90.6-97.4)$ & 154 & 146 & $95.2(90.4-97.7)$ \\
\hline 2 doses & 150 & 138 & $94.0(88.2-97.1)$ & 1060 & 1013 & $96.1(94.4-97.4)$ \\
\hline
\end{tabular}

Cl, confidence interval; COVID-19, coronavirus disease 2019; N, nucleocapsid protein; S1-RBD, spike protein of the receptor binding domain 
Table 4: Seroprevalence of select characteristics by vaccination status, General population, June - July 2021

\begin{tabular}{|c|c|c|c|c|c|c|c|c|c|}
\hline \multirow[b]{2}{*}{ Characteristics } & \multicolumn{3}{|c|}{ Unvaccinated } & \multicolumn{3}{|c|}{ Vaccinated with one dose } & \multicolumn{3}{|c|}{ Vaccinated with two doses } \\
\hline & Tested & $\begin{array}{l}\text { Positives } \\
\text { N/S }\end{array}$ & $\begin{array}{l}\text { Cluster and test } \\
\text { adjusted } \\
\text { Seroprevalence \% } \\
(95 \% \mathrm{Cl})\end{array}$ & Tested & $\begin{array}{l}\text { Positives } \\
\text { N/S }\end{array}$ & $\begin{array}{l}\text { Cluster and test } \\
\text { adjusted } \\
\text { Seroprevalence \% } \\
(95 \% \mathrm{Cl})\end{array}$ & Tested & $\begin{array}{l}\text { Positives } \\
\text { N/S }\end{array}$ & \begin{tabular}{|l|} 
Cluster and test \\
adjusted \\
Seroprevalence \% \\
$(95 \% \mathrm{Cl})$
\end{tabular} \\
\hline \multicolumn{10}{|l|}{ Age, years } \\
\hline $18-44$ & 8986 & 5381 & $60.8(59.2-62.3)$ & 2426 & 1896 & $80.4(78.2$ - 82.4$)$ & 1096 & 958 & 89.1 (86.7 - 91.3) \\
\hline $45-60$ & 2701 & 1778 & $67.0(64.8-69.1)$ & 1830 & 1521 & $85.5(83.4-87.3)$ & 1013 & 917 & $91.9(89.7-93.6)$ \\
\hline$>60$ & 912 & 599 & $67.0(63.6-70.4)$ & 782 & 599 & $78.9(75.4-82.0)$ & 522 & 456 & $88.7(85.4-91.5)$ \\
\hline \multicolumn{10}{|l|}{ Sex } \\
\hline Male & 10040 & 5962 & $59.6(57.8-61.4)$ & 2598 & 2050 & $81.0(79.0-82.9)$ & 1136 & 999 & $89.4(87.1-91.5)$ \\
\hline Female & 11223 & 6998 & $64.9(63.2-66.4)$ & 2436 & 1962 & $83.1(81.1-84.9)$ & 1493 & 1330 & $90.7(88.6-92.3)$ \\
\hline Other & 26 & 17 & $74.0(44.9-90.8)$ & 4 & 4 & - & 2 & 2 & - \\
\hline \multicolumn{10}{|l|}{ Area of residence } \\
\hline Rural & 3702 & 2280 & $62.1(60.5-63.7)$ & 1046 & 846 & $81.1(79.2-82.9)$ & 515 & 459 & $90.1(88.0-91.7)$ \\
\hline Urban non-slum & 16236 & 9832 & $63.6(60.2-66.8)$ & 3603 & 2840 & $83.2(79.8-86.1)$ & 1941 & 1716 & $90.4(86.9-93.0)$ \\
\hline Urban slum & 1351 & 865 & $64.6(59.0-69.8)$ & 389 & 330 & $87.1(82.1-90.9)$ & 175 & 156 & $90.9(84.7-94.7)$ \\
\hline \multicolumn{10}{|c|}{ Previous COVID-19 test result } \\
\hline $\begin{array}{l}\text { Reported positive for } \\
\text { COVID-19 }\end{array}$ & 487 & 402 & $86.0(82.2-89.1)$ & 145 & 134 & $94.7(90.1-97.2)$ & 150 & 138 & $93.8(88.6-96.7)$ \\
\hline Don't know & 119 & 58 & $60.2(46.5-72.5)$ & 36 & 28 & $84.1(67.5-93.1)$ & 16 & 11 & $66.7(37.4-87.0)$ \\
\hline \multicolumn{10}{|l|}{ Vaccine type } \\
\hline Covaxin & - & - & - & 385 & 302 & $80.8(75.7-85.0)$ & 202 & 171 & $86.3(80.4-90.8)$ \\
\hline Covishield & $-{ }_{-1}$ & - & - & 4565 & 3636 & $82.0(80.3-83.6)$ & 2380 & 2115 & $90.3(88.5-91.8)$ \\
\hline \multicolumn{10}{|c|}{ Optimal interval between vaccination and blood sample collection* (21 days after $1^{\text {st }}$ dose, 7 days after $2^{\text {nd }}$ dose $)$} \\
\hline Covaxin & - & - & - & 223 & 186 & $84.3(78.4-88.9)$ & 201 & 170 & $86.3(80.3-90.7)$ \\
\hline Covishield & - & - & - & 3045 & 2535 & $84.8(83.1-86.5)$ & 2380 & 2115 & $90.3(88.5-91.8)$ \\
\hline
\end{tabular}




\section{Supplementary Material}

Contents

1. Statistical Analysis

2. Sensitivity and Specificity estimated by external studies and in-house validation of Abbott and Siemens assay

3. Cluster adjusted proportion of individuals with SARS-CoV-2 IgG antibodies by states, fourth national SARS-CoV-2 serosurvey, India, June-July 2021.

4. Unweighted proportion of individuals with SARS-CoV-2 IgG antibodies by districts, fourth national SARS-CoV-2 serosurvey June-July2021.

5. Unweighted proportion of individuals with SARS-CoV-2 IgG antibodies among unvaccinated and aged above 10 years by districts, third and fourth national SARS-CoV-2 serosurvey, India

6. Seroprevalence of selected characteristics by vaccination status, Healthcare workers, June - July 2021.

7. Seroprevalence of IgG antibodies against Nucleocapsid by selected characteristics, JuneJuly 2021.

8. Estimated number of infections among individuals aged 6 years above and infection case ratio.

9. Comparison of seroprevalence against N/S-antibody by demographic characteristics between third and fourth serosurvey 


\section{Statistical Analysis}

The survey was conducted in 70 randomly selected districts. From each selected district, 10 villages/wards were selected by probability proportional to size method. Design weights were computed by the inverse of product of probabilities at all stages of selection (i.e. selection of villages/wards within districts and households). The design weights were normalized and attached to the master dataset.

Random effects logistic regression model was used to address the clustering effect of estimates by considering district as the level. A random intercept model with design weights was used to estimate the overall seroprevalence. Further, seroprevalence estimates for other factors like age, gender was estimated using the same model. Seroprevalence estimates were obtained by exponentiating the log odds values obtained from the model and converting into probability and its corresponding 95\% Wald confidence interval were obtained.

Reproduced from:

Murhekar MV, Bhatnagar T, Selvaraju S et al. SARS-CoV-2 antibody seroprevalence in India, August-September, 2020: findings from the second nationwide household serosurvey. Lancet Glob Health. 2021 Mar;9(3):e257-e266. 


\section{Sensitivity and Specificity estimated by external studies and in-house validation of Abbott and Siemens assay}

\begin{tabular}{|c|c|c|c|c|}
\hline \multirow[t]{2}{*}{ Source } & \multicolumn{2}{|l|}{ Abbott assay } & \multicolumn{2}{|l|}{ Siemens assay } \\
\hline & Sensitivity & Specificity & Sensitivity & Specificity \\
\hline Irsara C et al ${ }^{1}$ & $90.8 \%(86.3-93.9)$ & 99.3\% (97.6-99.8) & & \\
\hline Irsara C et al ${ }^{2}$ & & & $90.5 \%(85.2-94.3)$ & $99.4 \%(96.6-100.0)$ \\
\hline Tang MS 3 & $93.8 \%(82.8-98.7)$ & 99.4\% (96.4-99.9\%) & & \\
\hline Suhandynata $\mathrm{RT}^{4}$ & $92.60 \%$ & $100 \%$ & & \\
\hline Theel ES 5 & $95.70 \%$ & $99.60 \%$ & & \\
\hline Padoan $\mathrm{A}^{6}$ & $95.2 \%(89.1-98.4)$ & $100.0 \%(93.4-100.0)$ & & \\
\hline Manalac J7 & $97.90 \%$ & $99.60 \%$ & & \\
\hline Hubbard $\mathrm{JA}^{8}$ & $91.3 \%(72.0-98.9)$ & $100 \%(99.05-100.00)$ & & \\
\hline $\begin{array}{l}\text { National SARS-CoV-2 Serology } \\
\text { Assay Evaluation Group. }{ }^{9}\end{array}$ & $92.7 \%(90.2-94.8)$ & $99.9 \%(99.4-100)$ & & \\
\hline In house validation of Kits & $61.4 \%(52.8-69.5)$ & $100 \%(96.4-100)$ & $80.0 \%(72.4-86.3)$ & $99.0 \%(94.6-100.0)$ \\
\hline
\end{tabular}


1. Irsara C, Egger A, Prokop W et al. Evaluation of four commercial, fully automated SARS-CoV-2 antibody tests suggests a revision of the Siemens SARS-CoV-2 IgG assay. Clinical Chemistry and Laboratory Medicine (CCLM). 2021;(). https://doi.org/10.1515/cclm2020-1758.

2. Irsara C, Egger AE, Prokop W, Nairz M, Loacker L, Sahanic S, Pizzini A, Sonnweber T, Holzer B, Mayer W, Schennach H, LoefflerRagg J, Bellmann-Weiler R, Hartmann B, Tancevski I, Weiss G, Binder CJ, Anliker M, Griesmacher A, Hoermann G. Clinical validation of the Siemens quantitative SARS-CoV-2 spike IgG assay (sCOVG) reveals improved sensitivity and a good correlation with virus neutralization titers. Clin Chem Lab Med. 2021 Apr 9;59(8):1453-1462. doi: 10.1515/cclm-2021-0214. PMID: 33837679.

3. Tang MS, Hock KG, Logsdon NM, et al. Clinical Performance of Two SARS-CoV-2 Serologic Assays. Clin Chem. 2020;66(8):10551062. doi:10.1093/clinchem/hvaa120

4. Suhandynata RT, Hoffman MA, Kelner MJ, McLawhon RW, Reed SL, Fitzgerald RL. Multi-Platform Comparison of SARS-CoV-2 Serology Assays for the Detection of COVID-19. J Appl Lab Med. 2020 Nov 1;5(6):1324-1336. doi: 10.1093/jalm/jfaa139. PMID: 32766840; PMCID: PMC7454554.

5. E.S. Theel, J. Harring, H. Hilgart, D. Granger, Performance characteristics of four high-throughput immunoassays for detection of IgG antibodies against SARS-CoV-2, J. Clin. Microbiol. (2020), https://doi.org/10.1128/JCM.01243-20.

6. Padoan A, Bonfante F, Pagliari M, Bortolami A, Negrini D, Zuin S, Bozzato D, Cosma C, Sciacovelli L, Plebani M. Analytical and clinical performances of five immunoassays for the detection of SARS-CoV-2 antibodies in comparison with neutralization activity. EBioMedicine. 2020 Dec;62:103101. doi: 10.1016/j.ebiom.2020.103101. Epub 2020 Nov 4. PMID: 33160207; PMCID: PMC7640894.

7. Manalac J, Yee J, Calayag K, Nguyen L, Patel PM, Zhou D, Shi RZ. Evaluation of Abbott anti-SARS-CoV-2 CMIA IgG and Euroimmun ELISA IgG/lgA assays in a clinical lab. Clin Chim Acta. 2020 Nov;510:687-690. doi: 10.1016/j.cca.2020.09.002. Epub 2020 Sep 8. PMID: 32910980; PMCID: PMC7476889.

8. Hubbard JA, Geno KA, Khan J, Szczepiorkowski ZM, de Gijsel D, Ovalle AA, AISalman AS, Gallagher TL, Johnston AA, Tibbetts AR, Vital SE, Cervinski MA, Nerenz RD. Comparison of Two Automated Immunoassays for the Detection of SARS-CoV-2 Nucleocapsid Antibodies. J Appl Lab Med. 2021 Mar 1;6(2):429-440. doi: 10.1093/jalm/jfaa175. PMID: 32976593; PMCID: PMC7543392.

9. National SARS-CoV-2 Serology Assay Evaluation Group. Performance characteristics of five immunoassays for SARS-CoV-2: a headto-head benchmark comparison. Lancet Infect Dis. 2020 Dec;20(12):1390-1400. doi: 10.1016/S1473-3099(20)30634-4. Epub 2020 Sep 23. Erratum in: Lancet Infect Dis. 2020 Dec;20(12):e298. PMID: 32979318; PMCID: PMC7511171. 
3. Cluster adjusted proportion of individuals with SARS-CoV-2 IgG antibodies by states, fourth national SARS-CoV-2 serosurvey, India, June-July 2021

\begin{tabular}{|l|r|l|l|}
\hline State/Union Territory & $\begin{array}{l}\text { Total } \\
\text { Tested }\end{array}$ & $\begin{array}{l}\text { Positive for either anti-N } \\
\text { or anti-S }\end{array}$ & $\begin{array}{l}\text { Cluster Adjusted Seroprevalence \% (95\% } \\
\text { Cl) }\end{array}$ \\
\hline Madhya Pradesh & 1229 & 683 & $80.0(76.3-83.2)$ \\
\hline Rajasthan & 1226 & 628 & $77.1(73.2-80.7)$ \\
\hline Bihar & 2461 & 1174 & $76.7(73.9-79.3)$ \\
\hline Gujarat & 1219 & 540 & $76.4(72.4-80.1)$ \\
\hline Chhattisgarh & 1198 & 509 & $75.7(71.6-79.4)$ \\
\hline Uttarakhand & 401 & 202 & $74.2(66.7-80.6)$ \\
\hline Uttar Pradesh & 3733 & 1848 & $71.7(69.3-74.1)$ \\
\hline Andhra Pradesh & 1260 & 462 & $71.2(66.8-75.2)$ \\
\hline Karnataka & 1326 & 535 & $70.3(65.9-74.4)$ \\
\hline Tamil Nadu & 1258 & 524 & $70.1(65.6-74.2)$ \\
\hline Odisha & 1230 & 437 & $68.9(64.3-73.1)$ \\
\hline Punjab & 1581 & 597 & $67.2(63.2-71.0)$ \\
\hline Telangana & 1373 & 512 & $63.5(58.8-67.9)$ \\
\hline Jammu \& Kashmir & 430 & 124 & $63.4(55.0-71.0)$ \\
\hline Himachal Pradesh & 400 & 82 & $62.5(54.0-70.3)$ \\
\hline Jharkhand & 1231 & 415 & $61.9(57.1-66.6)$ \\
\hline West Bengal & 2042 & 529 & $61.3(57.6-65.0)$ \\
\hline Haryana & 398 & 137 & $60.4(51.8-68.4)$ \\
\hline Maharashtra & 2468 & 785 & $58.4(54.9-61.8)$ \\
\hline Assam & 1203 & 285 & $50.3(45.3-55.3)$ \\
\hline Kerala & 1308 & 281 & $44.3(39.5-49.2)$ \\
\hline
\end{tabular}


4. Unweighted proportion of individuals with SARS-CoV-2 IgG antibodies by districts, fourth national SARS-CoV-2 serosurvey, India, JuneJuly 2021

\begin{tabular}{|c|c|c|c|c|c|}
\hline District & State & $\begin{array}{l}\text { Total } \\
\text { Tested }\end{array}$ & N Positive (\%) & S Positive (\%) & N/S Positive (\%) \\
\hline Buxar & Bihar & 400 & $216(54.0)$ & $335(83.8)$ & $347(86.8)$ \\
\hline Gwalior & Madhya Pradesh & 416 & $219(52.6)$ & $330(79.3)$ & $340(81.7)$ \\
\hline Dewas & Madhya Pradesh & 407 & $230(56.5)$ & $319(78.4)$ & $330(81.1)$ \\
\hline Vizianagaram & Andhra Pradesh & 434 & $196(45.2)$ & $340(78.3)$ & $346(79.7)$ \\
\hline Surguja & Chhattisgarh & 397 & $176(44.3)$ & $301(75.8)$ & $316(79.6)$ \\
\hline Chennai & Tamil Nadu & 415 & $184(44.3)$ & $320(77.1)$ & $330(79.5)$ \\
\hline Madhubani & Bihar & 424 & $213(50.2)$ & 327 (77.1) & $337(79.5)$ \\
\hline Jalor & Rajasthan & 409 & $207(50.6)$ & $310(75.8)$ & $323(79.0)$ \\
\hline Sabar Kantha & Gujarat & 402 & $183(45.5)$ & $303(75.4)$ & $313(77.9)$ \\
\hline Arwal & Bihar & 410 & $202(49.3)$ & $302(73.7)$ & $317(77.3)$ \\
\hline Balrampur & Uttar Pradesh & 431 & $192(44.5)$ & 317 (73.5) & $331(76.8)$ \\
\hline Rajsamand & Rajasthan & 410 & $215(52.4)$ & $294(71.7)$ & $308(75.1)$ \\
\hline Narmada & Gujarat & 398 & $160(40.2)$ & $289(72.6)$ & $297(74.6)$ \\
\hline Dausa & Rajasthan & 407 & $206(50.6)$ & $280(68.8)$ & $303(74.4)$ \\
\hline Begusarai & Bihar & 417 & $186(44.6)$ & $303(72.7)$ & $310(74.3)$ \\
\hline Ujjain & Madhya Pradesh & 406 & $234(57.6)$ & $286(70.4)$ & $301(74.1)$ \\
\hline Mau & Uttar Pradesh & 455 & $245(53.8)$ & $328(72.1)$ & $337(74.1)$ \\
\hline Saharanpur & Uttar Pradesh & 399 & $220(55.1)$ & 275 (68.9) & 295 (73.9) \\
\hline Mahisagar & Gujarat & 419 & $197(47.0)$ & $294(70.2)$ & $308(73.5)$ \\
\hline Ludhiana & Punjab & 394 & $158(40.1)$ & $279(70.8)$ & $288(73.1)$ \\
\hline Garhwal & Uttarakhand & 401 & $202(50.4)$ & $273(68.1)$ & $293(73.1)$ \\
\hline Unnao & Uttar Pradesh & 395 & $202(51.1)$ & $270(68.4)$ & $288(72.9)$ \\
\hline
\end{tabular}




\begin{tabular}{|c|c|c|c|c|c|}
\hline District & State & $\begin{array}{c}\text { Total } \\
\text { Tested }\end{array}$ & N Positive (\%) & S Positive (\%) & N/S Positive (\%) \\
\hline Auraiya & Uttar Pradesh & 398 & $234(58.8)$ & $259(65.1)$ & $290(72.9)$ \\
\hline Kabeerdham & Chhattisgarh & 403 & $192(47.6)$ & $267(66.3)$ & $293(72.7)$ \\
\hline Ganjam & Odisha & 419 & $154(36.8)$ & $297(70.9)$ & $304(72.6)$ \\
\hline Bangalore & Karnataka & 447 & $165(36.9)$ & $313(70.0)$ & $323(72.3)$ \\
\hline Bijapur & Chhattisgarh & 398 & $141(35.4)$ & $272(68.3)$ & $285(71.6)$ \\
\hline Bareilly & Uttar Pradesh & 400 & $185(46.3)$ & $261(65.3)$ & $284(71.0)$ \\
\hline Gautam Buddha Nagar & Uttar Pradesh & 398 & $186(46.7)$ & $265(66.6)$ & $281(70.6)$ \\
\hline Muzaffarpur & Bihar & 404 & $194(48.0)$ & $264(65.3)$ & $281(69.6)$ \\
\hline Tiruvannamalai & Tamil Nadu & 415 & $168(40.5)$ & $282(68.0)$ & $288(69.4)$ \\
\hline Gulbarga & Karnataka & 428 & $177(41.4)$ & $288(67.3)$ & $296(69.2)$ \\
\hline Simdega & Jharkhand & 400 & $151(37.8)$ & $261(65.3)$ & $275(68.8)$ \\
\hline Gonda & Uttar Pradesh & 457 & $232(50.8)$ & $293(64.1)$ & $314(68.7)$ \\
\hline Bankura & West Bengal & 411 & $144(35.0)$ & $274(66.7)$ & $281(68.4)$ \\
\hline Kamareddy & Telangana & 471 & $186(39.5)$ & $309(65.6)$ & $322(68.4)$ \\
\hline Chitradurga & Karnataka & 451 & $193(42.8)$ & $293(65.0)$ & $307(68.1)$ \\
\hline Krishna & Andhra Pradesh & 409 & $144(35.2)$ & $266(65.0)$ & $278(68.0)$ \\
\hline Jalandhar & Punjab & 398 & $148(37.2)$ & $261(65.6)$ & $270(67.8)$ \\
\hline Purnia & Bihar & 406 & $163(40.1)$ & $263(64.8)$ & $275(67.7)$ \\
\hline Gurdaspur & Punjab & 390 & $144(36.9)$ & $247(63.3)$ & $261(66.9)$ \\
\hline Latehar & Jharkhand & 422 & $180(42.7)$ & $239(56.6)$ & $279(66.1)$ \\
\hline Rayagada & Odisha & 411 & $134(32.6)$ & $259(63.0)$ & $271(65.9)$ \\
\hline Koraput & Odisha & 400 & $149(37.3)$ & $245(61.3)$ & $263(65.8)$ \\
\hline South Twenty Four Parganas & West Bengal & 412 & $106(25.7)$ & $257(62.4)$ & $260(63.1)$ \\
\hline Pulwama & Jammu \& Kashmir & 430 & $124(28.8)$ & $263(61.2)$ & $271(63.0)$ \\
\hline
\end{tabular}




\begin{tabular}{|c|c|c|c|c|c|}
\hline District & State & $\begin{array}{c}\text { Total } \\
\text { Tested }\end{array}$ & N Positive (\%) & S Positive (\%) & N/S Positive (\%) \\
\hline Sri Potti Sriramulu Nellore & Andhra Pradesh & 417 & $122(29.3)$ & $253(60.7)$ & $261(62.6)$ \\
\hline Parbhani & Maharashtra & 420 & $130(31.0)$ & $252(60.0)$ & $262(62.4)$ \\
\hline Nanded & Maharashtra & 403 & $141(35.0)$ & $242(60.0)$ & $251(62.3)$ \\
\hline Kullu & Himachal Pradesh & 400 & $82(20.5)$ & $243(60.8)$ & $248(62.0)$ \\
\hline Alipurduar & West Bengal & 408 & $83(20.3)$ & $241(59.1)$ & $247(60.5)$ \\
\hline Nalgonda & Telangana & 451 & $171(37.9)$ & $252(55.9)$ & $273(60.5)$ \\
\hline Jangoan & Telangana & 451 & $155(34.4)$ & $265(58.8)$ & $271(60.1)$ \\
\hline Kurukshetra & Haryana & 398 & $137(34.4)$ & $218(54.8)$ & $239(60.1)$ \\
\hline Ahmadnagar & Maharashtra & 419 & $131(31.3)$ & $243(58.0)$ & $251(59.9)$ \\
\hline Coimbatore & Tamil Nadu & 428 & $172(40.2)$ & $244(57.0)$ & $252(58.9)$ \\
\hline Patiala & Punjab & 399 & $147(36.8)$ & $210(52.6)$ & $233(58.4)$ \\
\hline Jalgaon & Maharashtra & 414 & $155(37.4)$ & $211(51.0)$ & $241(58.2)$ \\
\hline Jyotiba Phule Nagar & Uttar Pradesh & 400 & $152(38.0)$ & $205(51.3)$ & $230(57.5)$ \\
\hline Purba Medinipur & West Bengal & 401 & $83(20.7)$ & $216(53.9)$ & $225(56.1)$ \\
\hline Jhargram & West Bengal & 410 & $113(27.6)$ & $222(54.1)$ & $230(56.1)$ \\
\hline Kamrup Metropolitan & Assam & 399 & $110(27.6)$ & $211(52.9)$ & $219(54.9)$ \\
\hline Sangli & Maharashtra & 410 & $102(24.9)$ & $218(53.2)$ & $225(54.9)$ \\
\hline Udalguri & Assam & 401 & $82(20.4)$ & $199(49.6)$ & $207(51.6)$ \\
\hline Bid & Maharashtra & 402 & $126(31.3)$ & $169(42.0)$ & $202(50.2)$ \\
\hline Thrissur & Kerala & 437 & $107(24.5)$ & $206(47.1)$ & $216(49.4)$ \\
\hline Pakur & Jharkhand & 409 & $84(20.5)$ & $180(44.0)$ & $199(48.7)$ \\
\hline Karbi Anglong & Assam & 403 & $93(23.1)$ & $162(40.2)$ & $179(44.4)$ \\
\hline Palakkad & Kerala & 439 & $94(21.4)$ & $184(41.9)$ & $190(43.3)$ \\
\hline Ernakulam & Kerala & 432 & $80(18.5)$ & 169 (39.1) & $175(40.5)$ \\
\hline
\end{tabular}


5. Unweighted proportion of individuals with SARS-CoV-2 IgG antibodies among unvaccinated and aged above 10 years by districts, third and fourth national SARS-CoV-2 serosurvey, India

\begin{tabular}{|c|c|c|c|c|c|c|c|c|c|c|}
\hline \multirow{2}{*}{ State } & \multirow{2}{*}{ District } & \multicolumn{4}{|c|}{$\begin{array}{c}\text { General Population (Unvaccinated and }>=10 \text { Years) } \\
\text { ROUND } 3\end{array}$} & \multicolumn{4}{|c|}{$\begin{array}{c}\text { General Population (Unvaccinated and }>=10 \text { Years) } \\
\text { ROUND } 4\end{array}$} & \multirow{2}{*}{$\begin{array}{l}\text { Ratio of } \\
\text { N/S }\end{array}$} \\
\hline & & $\begin{array}{r}\text { Total } \\
\text { Tested } \\
\end{array}$ & $\begin{array}{r}\text { N Positive } \\
(\%) \\
\end{array}$ & $\begin{array}{r}\text { S Positive } \\
(\%) \\
\end{array}$ & $\begin{array}{r}\text { N/S Positive } \\
(\%) \\
\end{array}$ & $\begin{array}{r}\text { Total } \\
\text { Tested } \\
\end{array}$ & $\begin{array}{r}\text { N Positive } \\
(\%) \\
\end{array}$ & $\begin{array}{r}\text { S Positive } \\
(\%)\end{array}$ & $\begin{array}{r}\mathrm{N} / \mathrm{S} \\
\text { Positive (\%) } \\
\end{array}$ & \\
\hline Gujarat & Mahisagar & 407 & $11(2.7)$ & $15(3.7)$ & $20(4.9)$ & 171 & 84 (49.1) & $108(63.2)$ & 113 (66.1) & 13.5 \\
\hline Chhattisgarh & Surguja & 396 & $33(8.3)$ & $31(7.8)$ & $43(10.9)$ & 250 & $126(50.4)$ & $186(74.4)$ & 199 (79.6) & 7.3 \\
\hline Gujarat & Narmada & 401 & $41(10.2)$ & $42(10.5)$ & $47(11.7)$ & 216 & 91 (42.1) & $141(65.3)$ & 148 (68.5) & 5.9 \\
\hline Uttar Pradesh & Saharanpur & 396 & $41(10.4)$ & 51 (12.9) & $60(15.2)$ & 294 & $167(56.8)$ & 192 (65.3) & 211 (71.8) & 4.7 \\
\hline Uttar Pradesh & Gonda & 417 & $31(7.4)$ & $54(12.9)$ & $60(14.4)$ & 285 & 139 (48.8) & $178(62.5)$ & $191(67.0)$ & 4.7 \\
\hline $\begin{array}{l}\text { Madhya } \\
\text { Pradesh }\end{array}$ & Dewas & 390 & 51 (13.1) & 58 (14.9) & $73(18.7)$ & 274 & $160(58.4)$ & 209 (76.3) & 219 (79.9) & 4.3 \\
\hline Rajasthan & Rajsamand & 404 & $58(14.4)$ & 57 (14.1) & 69 (17.1) & 265 & $148(55.8)$ & 179 (67.5) & 192 (72.5) & 4.2 \\
\hline Jharkhand & Latehar & 398 & 37 (9.3) & 48 (12.1) & 60 (15.1) & 256 & $117(45.7)$ & $133(52.0)$ & $163(63.7)$ & 4.2 \\
\hline Bihar & Begusarai & 413 & 48 (11.6) & $62(15.0)$ & 77 (18.6) & 255 & $125(49.0)$ & $172(67.5)$ & 179 (70.2) & 3.8 \\
\hline Uttar Pradesh & Balrampur & 390 & 58 (14.9) & 62 (15.9) & $80(20.5)$ & 302 & 139 (46.0) & 216 (71.5) & $229(75.8)$ & 3.7 \\
\hline Uttarakhand & Garhwal & 399 & 61 (15.3) & 66 (16.5) & 77 (19.3) & 185 & $117(63.2)$ & 114 (61.6) & $131(70.8)$ & 3.7 \\
\hline Uttar Pradesh & Unnao & 401 & $44(11.0)$ & 66 (16.5) & 76 (19.0) & 250 & 125 (50.0) & $156(62.4)$ & $171(68.4)$ & 3.6 \\
\hline Rajasthan & Dausa & 390 & 49 (12.6) & 62 (15.9) & 75 (19.2) & 249 & 132 (53.0) & $146(58.6)$ & $166(66.7)$ & 3.5 \\
\hline Chhattisgarh & Kabeerdham & 399 & 54 (13.5) & 73 (18.3) & $81(20.3)$ & 290 & $138(47.6)$ & $184(63.4)$ & 204 (70.3) & 3.5 \\
\hline Gujarat & Sabar Kantha & 399 & $62(15.5)$ & $75(18.8)$ & $83(20.8)$ & 220 & $96(43.6)$ & 145 (65.9) & 155 (70.5) & 3.4 \\
\hline $\begin{array}{l}\text { Madhya } \\
\text { Pradesh }\end{array}$ & Ujjain & 405 & 53 (13.1) & 78 (19.3) & $84(20.7)$ & 271 & 155 (57.2) & $173(63.8)$ & $188(69.4)$ & 3.4 \\
\hline Punjab & Jalandhar & 398 & 55 (13.8) & 66 (16.6) & 77 (19.3) & 245 & 85 (34.7) & $152(62.0)$ & 158 (64.5) & 3.3 \\
\hline
\end{tabular}




\begin{tabular}{|c|c|c|c|c|c|c|c|c|c|c|}
\hline \multirow{2}{*}{ State } & \multirow{2}{*}{ District } & \multicolumn{4}{|c|}{$\begin{array}{c}\text { General Population (Unvaccinated and }>=10 \text { Years) } \\
\text { ROUND } 3\end{array}$} & \multicolumn{4}{|c|}{$\begin{array}{c}\text { General Population (Unvaccinated and }>=10 \text { Years) } \\
\text { ROUND } 4\end{array}$} & \multirow{2}{*}{$\begin{array}{c}\text { Ratio of } \\
\text { N/S }\end{array}$} \\
\hline & & $\begin{array}{r}\text { Total } \\
\text { Tested } \\
\end{array}$ & $\begin{array}{r}\text { N Positive } \\
(\%) \\
\end{array}$ & $\begin{array}{r}\text { S Positive } \\
(\%) \\
\end{array}$ & $\begin{array}{r}\text { N/S Positive } \\
(\%) \\
\end{array}$ & $\begin{array}{r}\text { Total } \\
\text { Tested } \\
\end{array}$ & $\begin{array}{r}\text { N Positive } \\
(\%) \\
\end{array}$ & $\begin{array}{r}\text { S Positive } \\
(\%) \\
\end{array}$ & $\begin{array}{r}\mathrm{N} / \mathrm{S} \\
\text { Positive (\%) } \\
\end{array}$ & \\
\hline Haryana & Kurukshetra & 397 & 45 (11.3) & 60 (15.1) & 66 (16.6) & 243 & 78 (32.1) & 110 (45.3) & 127 (52.3) & 3.2 \\
\hline Rajasthan & Jalor & 409 & 75 (18.3) & 74 (18.1) & 93 (22.7) & 195 & 104 (53.3) & 123 (63.1) & $134(68.7)$ & 3.0 \\
\hline Kerala & Thrissur & 418 & $50(12.0)$ & 36 (8.6) & 59 (14.1) & 278 & $71(25.5)$ & 109 (39.2) & 117 (42.1) & 3.0 \\
\hline Bihar & Buxar & 422 & $71(16.8)$ & 110 (26.1) & $121(28.7)$ & 233 & $129(55.4)$ & 189 (81.1) & $198(85.0)$ & 3.0 \\
\hline Kerala & Palakkad & 408 & 46 (11.3) & 55 (13.5) & $58(14.2)$ & 325 & $72(22.2)$ & $130(40.0)$ & $136(41.8)$ & 2.9 \\
\hline Jharkhand & Simdega & 400 & $59(14.8)$ & $68(17.0)$ & 78 (19.5) & 193 & 70 (36.3) & $101(52.3)$ & $110(57.0)$ & 2.9 \\
\hline Uttar Pradesh & Auraiya & 398 & 61 (15.3) & $86(21.6)$ & 99 (24.9) & 304 & $186(61.2)$ & $188(61.8)$ & 219 (72.0) & 2.9 \\
\hline Bihar & Muzaffarpur & 401 & $41(10.2)$ & $87(21.7)$ & $93(23.2)$ & 275 & 141 (51.3) & 169 (61.5) & 184 (66.9) & 2.9 \\
\hline Maharashtra & Parbhani & 426 & $46(10.8)$ & 81 (19.0) & $88(20.7)$ & 278 & 89 (32.0) & $154(55.4)$ & $163(58.6)$ & 2.8 \\
\hline Karnataka & Chitradurga & 442 & $67(15.2)$ & $96(21.7)$ & 103 (23.3) & 276 & $133(48.2)$ & $171(62.0)$ & 182 (65.9) & 2.8 \\
\hline Bihar & Arwal & 416 & 63 (15.1) & 109 (26.2) & $118(28.4)$ & 299 & $147(49.2)$ & $223(74.6)$ & 233 (77.9) & 2.7 \\
\hline Punjab & Ludhiana & 399 & $56(14.0)$ & 89 (22.3) & $101(25.3)$ & 271 & $113(41.7)$ & $182(67.2)$ & 187 (69.0) & 2.7 \\
\hline Uttar Pradesh & Mau & 417 & $72(17.3)$ & 89 (21.3) & 108 (25.9) & 319 & 172 (53.9) & 214 (67.1) & 223 (69.9) & 2.7 \\
\hline Punjab & Patiala & 400 & 59 (14.8) & $75(18.8)$ & $84(21.0)$ & 272 & 107 (39.3) & 132 (48.5) & 153 (56.3) & 2.7 \\
\hline Bihar & Madhubani & 404 & 63 (15.6) & $99(24.5)$ & $113(28.0)$ & 223 & 116 (52.0) & $157(70.4)$ & $165(74.0)$ & 2.6 \\
\hline $\begin{array}{l}\text { Madhya } \\
\text { Pradesh }\end{array}$ & Gwalior & 402 & 68 (16.9) & 107 (26.6) & $112(27.9)$ & 182 & $98(53.8)$ & 127 (69.8) & $134(73.6)$ & 2.6 \\
\hline Uttar Pradesh & Bareilly & 398 & $51(12.8)$ & 92 (23.1) & 97 (24.4) & 267 & 125 (46.8) & $153(57.3)$ & $171(64.0)$ & 2.6 \\
\hline Bihar & Purnia & 414 & $56(13.5)$ & $87(21.0)$ & $98(23.7)$ & 229 & $102(44.5)$ & 133 (58.1) & $141(61.6)$ & 2.6 \\
\hline Punjab & Gurdaspur & 399 & 75 (18.8) & 81 (20.3) & 101 (25.3) & 241 & 89 (36.9) & $148(61.4)$ & 158 (65.6) & 2.6 \\
\hline Telangana & Kamareddy & 413 & $51(12.3)$ & $102(24.7)$ & $106(25.7)$ & 314 & 126 (40.1) & 187 (59.6) & 199 (63.4) & 2.5 \\
\hline
\end{tabular}




\begin{tabular}{|c|c|c|c|c|c|c|c|c|c|c|}
\hline \multirow{2}{*}{ State } & \multirow{2}{*}{ District } & \multicolumn{4}{|c|}{$\begin{array}{c}\text { General Population (Unvaccinated and }>=10 \text { Years) } \\
\text { ROUND } 3\end{array}$} & \multicolumn{4}{|c|}{$\begin{array}{c}\text { General Population (Unvaccinated and }>=10 \text { Years) } \\
\text { ROUND } 4\end{array}$} & \multirow{2}{*}{$\begin{array}{l}\text { Ratio of } \\
\text { N/S }\end{array}$} \\
\hline & & $\begin{array}{r}\text { Total } \\
\text { Tested } \\
\end{array}$ & $\begin{array}{r}\text { N Positive } \\
(\%) \\
\end{array}$ & $\begin{array}{r}\text { S Positive } \\
(\%) \\
\end{array}$ & $\begin{array}{r}\text { N/S Positive } \\
(\%) \\
\end{array}$ & $\begin{array}{r}\text { Total } \\
\text { Tested } \\
\end{array}$ & $\begin{array}{r}\text { N Positive } \\
(\%) \\
\end{array}$ & $\begin{array}{r}\text { S Positive } \\
(\%) \\
\end{array}$ & $\begin{array}{r}\mathrm{N} / \mathrm{S} \\
\text { Positive (\%) } \\
\end{array}$ & \\
\hline Uttar Pradesh & $\begin{array}{l}\text { Jyotiba Phule } \\
\text { Nagar }\end{array}$ & 395 & $62(15.7)$ & $80(20.3)$ & $92(23.3)$ & 322 & $123(38.2)$ & $160(49.7)$ & $182(56.5)$ & 2.4 \\
\hline Jharkhand & Pakur & 397 & $44(11.1)$ & $63(15.9)$ & 75 (18.9) & 285 & $63(22.1)$ & 113 (39.6) & $128(44.9)$ & 2.4 \\
\hline Karnataka & Gulbarga & 429 & $47(11.0)$ & $113(26.3)$ & $117(27.3)$ & 268 & $118(44.0)$ & $161(60.1)$ & $168(62.7)$ & 2.3 \\
\hline Telangana & Nalgonda & 420 & $59(14.0)$ & $96(22.9)$ & $108(25.7)$ & 327 & $132(40.4)$ & $170(52.0)$ & $189(57.8)$ & 2.2 \\
\hline Tamil Nadu & Coimbatore & 411 & $69(16.8)$ & $91(22.1)$ & $100(24.3)$ & 289 & $117(40.5)$ & 149 (51.6) & $156(54.0)$ & 2.2 \\
\hline Tamil Nadu & Tiruvannamalai & 409 & $86(21.0)$ & $116(28.4)$ & 127 (31.1) & 274 & $123(44.9)$ & $182(66.4)$ & $187(68.2)$ & 2.2 \\
\hline Maharashtra & Ahmadnagar & 433 & $64(14.8)$ & $98(22.6)$ & $106(24.5)$ & 293 & $98(33.4)$ & $150(51.2)$ & $156(53.2)$ & 2.2 \\
\hline Kerala & Ernakulam & 420 & $38(9.0)$ & $54(12.9)$ & $61(14.5)$ & 234 & $48(20.5)$ & $70(29.9)$ & $73(31.2)$ & 2.2 \\
\hline Uttar Pradesh & $\begin{array}{l}\text { Gautam Buddha } \\
\text { Nagar }\end{array}$ & 398 & 77 (19.3) & $109(27.4)$ & $126(31.7)$ & 284 & $130(45.8)$ & $175(61.6)$ & $189(66.5)$ & 2.1 \\
\hline Karnataka & Bangalore & 418 & $81(19.4)$ & $126(30.1)$ & $142(34.0)$ & 284 & $116(40.8)$ & $193(68.0)$ & $201(70.8)$ & 2.1 \\
\hline West Bengal & Jhargram & 419 & $89(21.2)$ & $110(26.3)$ & $119(28.4)$ & 347 & $105(30.3)$ & 194 (55.9) & $202(58.2)$ & 2.0 \\
\hline Telangana & Jangoan & 427 & $59(13.8)$ & $106(24.8)$ & $112(26.2)$ & 323 & $114(35.3)$ & $164(50.8)$ & $170(52.6)$ & 2.0 \\
\hline Maharashtra & Nanded & 420 & $61(14.5)$ & $109(26.0)$ & $121(28.8)$ & 269 & $82(30.5)$ & $138(51.3)$ & 145 (53.9) & 1.9 \\
\hline Andhra Pradesh & $\begin{array}{l}\text { Sri Potti } \\
\text { Sriramulu } \\
\text { Nellore }\end{array}$ & 405 & $96(23.7)$ & $121(29.9)$ & $127(31.4)$ & 242 & $76(31.4)$ & $134(55.4)$ & $140(57.9)$ & 1.8 \\
\hline West Bengal & Bankura & 413 & $94(22.8)$ & $137(33.2)$ & $143(34.6)$ & 249 & $94(37.8)$ & $151(60.6)$ & $156(62.7)$ & 1.8 \\
\hline Andhra Pradesh & Vizianagaram & 410 & 57 (13.9) & $166(40.5)$ & $172(42.0)$ & 256 & $130(50.8)$ & $188(73.4)$ & $194(75.8)$ & 1.8 \\
\hline Odisha & Koraput & 401 & $96(23.9)$ & $124(30.9)$ & $140(34.9)$ & 262 & $106(40.5)$ & $142(54.2)$ & $160(61.1)$ & 1.8 \\
\hline Maharashtra & Jalgaon & 427 & $67(15.7)$ & $121(28.3)$ & 135 (31.6) & 297 & $115(38.7)$ & $138(46.5)$ & $162(54.5)$ & 1.7 \\
\hline Maharashtra & Bid & 421 & $57(13.5)$ & $98(23.3)$ & $106(25.2)$ & 264 & $85(32.2)$ & 88 (33.3) & $114(43.2)$ & 1.7 \\
\hline Tamil Nadu & Chennai & 408 & $72(17.6)$ & $166(40.7)$ & $175(42.9)$ & 240 & $111(46.3)$ & $167(69.6)$ & $174(72.5)$ & 1.7 \\
\hline
\end{tabular}




\begin{tabular}{|c|c|c|c|c|c|c|c|c|c|c|}
\hline \multirow{2}{*}{ State } & \multirow{2}{*}{ District } & \multicolumn{4}{|c|}{$\begin{array}{c}\text { General Population (Unvaccinated and }>=10 \text { Years) } \\
\text { ROUND } 3\end{array}$} & \multicolumn{4}{|c|}{$\begin{array}{c}\text { General Population (Unvaccinated and >=10 Years) } \\
\text { ROUND } 4\end{array}$} & \multirow{2}{*}{$\begin{array}{c}\text { Ratio of } \\
\text { N/S }\end{array}$} \\
\hline & & \begin{tabular}{r|} 
Total \\
Tested
\end{tabular} & $\begin{array}{r}\text { N Positive } \\
(\%)\end{array}$ & $\begin{array}{r}\text { S Positive } \\
(\%)\end{array}$ & $\begin{array}{r}\text { N/S Positive } \\
(\%)\end{array}$ & $\begin{array}{r}\text { Total } \\
\text { Tested }\end{array}$ & $\begin{array}{r}\text { N Positive } \\
(\%)\end{array}$ & $\begin{array}{r}\text { S Positive } \\
(\%)\end{array}$ & $\begin{array}{r}\mathrm{N} / \mathrm{S} \\
\text { Positive (\%) }\end{array}$ & \\
\hline Andhra Pradesh & Krishna & 403 & $70(17.4)$ & $148(36.7)$ & $154(38.2)$ & 238 & $90(37.8)$ & $138(58.0)$ & $147(61.8)$ & 1.6 \\
\hline $\begin{array}{l}\text { Jammu \& } \\
\text { Kashmir }\end{array}$ & Pulwama & 419 & $99(23.6)$ & 132 (31.5) & 145 (34.6) & 198 & $61(30.8)$ & $104(52.5)$ & $110(55.6)$ & 1.6 \\
\hline Chhattisgarh & Bijapur & 396 & $134(33.8)$ & 150 (37.9) & $176(44.4)$ & 274 & 109 (39.8) & 186 (67.9) & 195 (71.2) & 1.6 \\
\hline Assam & Karbi Anglong & 413 & $71(17.2)$ & $86(20.8)$ & $102(24.7)$ & 294 & $77(26.2)$ & $98(33.3)$ & 115 (39.1) & 1.6 \\
\hline Odisha & Ganjam & 408 & 95 (23.3) & $142(34.8)$ & $157(38.5)$ & 205 & $86(42.0)$ & $116(56.6)$ & $122(59.5)$ & 1.5 \\
\hline West Bengal & Purba Medinipur & 415 & 79 (19.0) & 124 (29.9) & $133(32.0)$ & 282 & $61(21.6)$ & $130(46.1)$ & $136(48.2)$ & 1.5 \\
\hline Odisha & Rayagada & 407 & $87(21.4)$ & $154(37.8)$ & $166(40.8)$ & 277 & $98(35.4)$ & $149(53.8)$ & 161 (58.1) & 1.4 \\
\hline West Bengal & $\begin{array}{l}\text { South } 24 \\
\text { Parganas }\end{array}$ & 414 & 103 (24.9) & $150(36.2)$ & $167(40.3)$ & 256 & $68(26.6)$ & $138(53.9)$ & $140(54.7)$ & 1.4 \\
\hline Assam & $\begin{array}{l}\text { Kamrup } \\
\text { Metropolitan }\end{array}$ & 408 & $89(21.8)$ & $134(32.8)$ & $150(36.8)$ & 259 & $77(29.7)$ & $118(45.6)$ & 125 (48.3) & 1.3 \\
\hline West Bengal & Alipurduar & 415 & $90(21.7)$ & 163 (39.3) & $175(42.2)$ & 310 & 64 (20.6) & 164 (52.9) & $170(54.8)$ & 1.3 \\
\hline $\begin{array}{l}\text { Himachal } \\
\text { Pradesh }\end{array}$ & Kullu & 400 & $153(38.3)$ & $141(35.3)$ & $166(41.5)$ & 186 & $46(24.7)$ & $94(50.5)$ & $99(53.2)$ & 1.3 \\
\hline Assam & Udalguri & 407 & $90(22.1)$ & $114(28.0)$ & 142 (34.9) & 271 & $55(20.3)$ & 112 (41.3) & 119 (43.9) & 1.3 \\
\hline Maharashtra & Sangli & 426 & $88(20.7)$ & 156 (36.6) & $161(37.8)$ & 243 & $61(25.1)$ & $100(41.2)$ & 106 (43.6) & 1.2 \\
\hline
\end{tabular}


6. Seroprevalence of selected characteristics by vaccination status, Healthcare workers, June - July 2021

\begin{tabular}{|c|c|c|c|c|c|c|c|c|c|}
\hline \multirow[b]{2}{*}{ Characteristics } & \multicolumn{3}{|c|}{ Unvaccinated } & \multicolumn{3}{|c|}{ Vaccinated with one dose } & \multicolumn{3}{|c|}{ Vaccinated with two doses } \\
\hline & Tested & $\begin{array}{c}\text { Positives } \\
\text { (N/S) }\end{array}$ & \begin{tabular}{|l} 
Cluster and test \\
adjusted \\
Seroprevalence \% \\
$(95 \% \mathrm{Cl})$ \\
\end{tabular} & Tested & $\begin{array}{c}\text { Positives } \\
\text { (N/S) }\end{array}$ & $\begin{array}{l}\text { Cluster and test adjusted } \\
\text { Seroprevalence \% (95\% } \\
\mathrm{Cl})\end{array}$ & Tested & $\begin{array}{c}\text { Positives } \\
\text { (N/S) }\end{array}$ & $\begin{array}{l}\text { Cluster and test adjusted } \\
\text { Seroprevalence \% (95\% } \\
\text { Cl) }\end{array}$ \\
\hline \multicolumn{10}{|l|}{ Age (years) } \\
\hline $18-44$ & 651 & 429 & $65.6(60.5-70.5)$ & 828 & 712 & $88.2(84.8-91.0)$ & 3654 & 3260 & $90.1(88.5-91.5)$ \\
\hline $45-60$ & 105 & 77 & $73.8(63.3-82.0)$ & 142 & 120 & $85.1(77.7-90.5)$ & 1750 & 1489 & $86.1(83.7-88.2)$ \\
\hline$>60$ & 3 & 1 & $35.6(3.8-87.4)$ & 2 & 2 & - & 117 & 96 & $81.9(73.2-88.2)$ \\
\hline \multicolumn{10}{|l|}{ Sex } \\
\hline Male & 343 & 230 & $66.0(59.7-72.0)$ & 451 & 392 & $88.3(84.4-91.5)$ & 2729 & 2402 & $88.7(86.9-90.4)$ \\
\hline Female & 414 & 277 & $67.4(61.4-72.9)$ & 521 & 442 & $87.1(83.0-90.4)$ & 2787 & 2438 & $88.5(86.7-90.3)$ \\
\hline Other & 2 & 0 & - & - & - & - & 5 & 5 & - \\
\hline \multicolumn{10}{|c|}{ Results of COVID-19 testing } \\
\hline $\begin{array}{l}\text { Reported positive for } \\
\text { COVID-19 }\end{array}$ & 140 & 116 & $85.0(77.0-90.6)$ & 154 & 146 & $95.6(90.9-97.9)$ & 1060 & 1013 & $96.3(94.9-97.3)$ \\
\hline $\begin{array}{l}\text { Reported Negative for } \\
\text { COVID-19 }\end{array}$ & 267 & 156 & $58.7(50.5-66.4)$ & 491 & 408 & $85.9(80.9-89.7)$ & 2637 & 2225 & $85.4(83.1-87.4)$ \\
\hline Don't know & 16 & 11 & $71.9(37.0-91.7)$ & 15 & 15 & - & 112 & 104 & $92.1(81.9-96.8)$ \\
\hline \multicolumn{10}{|l|}{ Vaccine type } \\
\hline Covaxin & - & - & - & 127 & 96 & $79.0(69.5-86.0)$ & 371 & 332 & $89.0(84.8-92.2)$ \\
\hline Covishield & - & - & - & 841 & 734 & $88.5(85.5-91.1)$ & 5132 & 4495 & $88.6(87.0-90.1)$ \\
\hline \multicolumn{10}{|c|}{ Optimal interval between vaccination and blood sample collection* (21 days after $1^{\text {st }}$ dose, 7 days after $2^{\text {nd }}$ dose) } \\
\hline Covaxin & - & - & 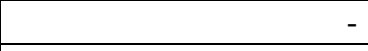 & 103 & 81 & $83.8(73.5-90.6)$ & 368 & 329 & $88.9(84.7-92.1)$ \\
\hline Covishield & - & - & - & 675 & 599 & $91.0(87.4-93.6)$ & 5127 & 4490 & $88.6(87.0-90.1)$ \\
\hline
\end{tabular}




\section{Seroprevalence of IgG antibodies against Nucleocapsid by selected characteristics, June-July 2021}

\begin{tabular}{|c|c|c|c|c|c|c|}
\hline \multirow[t]{2}{*}{ Characteristics } & \multicolumn{3}{|c|}{ General population } & \multicolumn{3}{|c|}{ Healthcare workers } \\
\hline & $\begin{array}{l}\text { No. } \\
\text { tested }\end{array}$ & $\begin{array}{l}\text { No. positive } \\
\text { (anti-N antibodies) }\end{array}$ & $\begin{array}{l}\text { Weighted and test- } \\
\text { performance-adjusted } \\
\text { seroprevalence } \\
\%(95 \% \mathrm{Cl})\end{array}$ & No. tested & $\begin{array}{l}\text { No. positive } \\
\text { (anti-N antibodies) }\end{array}$ & $\begin{array}{l}\text { Test-performance-adjusted } \\
\text { seroprevalence } \\
\%(95 \% \mathrm{Cl})\end{array}$ \\
\hline \multicolumn{7}{|l|}{ Age (years) } \\
\hline $6-9$ & 2892 & 1076 & $36.5(34.4-38.8)$ & - & - & - \\
\hline $10-17$ & 5798 & 2329 & $39.0(37.2-40.7)$ & - & - & - \\
\hline $18-44$ & 12522 & 4847 & $37.7(36.2$ - 39.1) & 5133 & 1635 & $31.0(28.7-33.4)$ \\
\hline $45-60$ & 5545 & 2149 & $38.3(36.4-40.0)$ & 1997 & 624 & $30.2(27.5-33.1)$ \\
\hline$>60$ & 2218 & 888 & $41.5(39.1-44.0)$ & 122 & 46 & $36.5(28.1-46.0)$ \\
\hline \multicolumn{7}{|l|}{ Sex } \\
\hline Male & 13783 & 5311 & $37.1(35.8-38.6)$ & 3523 & 1162 & $31.5(29.0-34.0)$ \\
\hline Female & 15160 & 5967 & $39.2(37.9-40.6)$ & 3722 & 1141 & $30.3(27.9-32.8)$ \\
\hline Other & 32 & 11 & $16.4(6.1-36.3)$ & 7 & 2 & $26.6(6.2-65.7)$ \\
\hline \multicolumn{7}{|l|}{ Area of residence } \\
\hline Rural & 21794 & 8556 & $39.0(37.6-40.4)$ & - & - & - \\
\hline Urban non-slum & 5266 & 1997 & $37.2(34.7-39.8)$ & - & - & - \\
\hline Urban slum & 1915 & 736 & $37.3(33.1-41.6)$ & - & - & - \\
\hline \multicolumn{7}{|c|}{ History of COVID-19 related symptoms since 1 Jan 2021} \\
\hline Yes & 1748 & 808 & $51.6(48.7-54.6)$ & 925 & 422 & $45.9(41.8-50.1)$ \\
\hline No & 27227 & 10481 & $37.6(36.3-38.8)$ & 6327 & 1883 & $28.7(26.5-31.0)$ \\
\hline \multicolumn{7}{|c|}{ Results of COVID-19 testing } \\
\hline $\begin{array}{l}\text { Reported positive for } \\
\text { COVID-19 }\end{array}$ & 782 & 464 & $63.4(59.8-66.7)$ & 1354 & 630 & $46.6(42.9-50.3)$ \\
\hline $\begin{array}{l}\text { Reported Negative for } \\
\text { COVID-19 }\end{array}$ & 3419 & 1222 & $38.1(35.8-40.3)$ & 3395 & 922 & $26.3(24.0-28.9)$ \\
\hline Don't know & 171 & 55 & $34.5(24.4-46.3)$ & 143 & 56 & $37.4(26.6-49.8)$ \\
\hline \multicolumn{7}{|c|}{ COVID-19 vaccination among adults } \\
\hline 0 dose & 12599 & 5122 & $40.3(38.9-41.7)$ & 759 & 339 & $43.2(39.0-47.5)$ \\
\hline 1 dose & 5038 & 1898 & $36.1(34.3-38.0)$ & 972 & 358 & $35.9(32.2-39.8)$ \\
\hline 2 doses & 2631 & 856 & $31.3(29.1-33.5)$ & 5521 & 1608 & $28.3(26.2-30.5)$ \\
\hline \multicolumn{7}{|l|}{ Vaccine type } \\
\hline Covaxin & 587 & 274 & $50.6(45.7-55.5)$ & 498 & 255 & $51.6(46.5-56.8)$ \\
\hline Covishield & 6945 & 2422 & $32.7(30.9-34.5)$ & 5973 & 1702 & $27.6(25.5-29.8)$ \\
\hline
\end{tabular}


8. Estimated number of infections among individuals aged 6 years above and infection case ratio

\begin{tabular}{|l|r|r|}
\hline & $\begin{array}{l}\text { Estimate (95\% Cl) by N/S - Seroprevalence } \\
\text { considering the unvaccinated population* }\end{array}$ & $\begin{array}{l}\text { Estimate (95\% Cl) by N/S - Seroprevalence } \\
\text { by considering the entire population** }\end{array}$ \\
\hline Estimated number of infections & $\begin{array}{r}64,27,51,546 \\
80,73,95,611 \\
(62,59,01,252-65,96,01,839)\end{array}$ & $2,90,88,245$ \\
\hline Number of reported COVID-19 cases (9 June 2021) & $2,90,88,245$ & $27.64,69,887-82,83,21,335)$ \\
\hline Infection Case ratio (9 June 2021) & $22.1(21.5-22.7)$ & $2,96,32,302$ \\
\hline Number of reported COVID-19 cases (16 June 2021) & $2,96,5)$ \\
\hline Infection Case ratio (16 June 2021) & $21.7(21.1-22.3)$ & $27.2(26.5-28.0)$ \\
\hline
\end{tabular}

* Applying the weighted seroprevalence to the population aged $6-17$ years and the unweighted seroprevalence among unvaccinated individuals aged 18 years and above to the total population of unvaccinated individuals aged $>=18$ years

** Applying the weighted seroprevalence to the population aged $6-17$ years and the weighted seroprevalence among unvaccinated individuals aged 18 years and above to the total population aged $>=18$ years 
9. Comparison of seroprevalence against N/S-antibody by demographic characteristics between third and fourth serosurvey

\begin{tabular}{|l|r|r|}
\hline & $\begin{array}{l}\text { Third serosurvey } \\
\text { Prevalence }(95 \% \mathrm{Cl})\end{array}$ & $\begin{array}{l}\text { Fourth serosurvey } \\
\text { Prevalence }(95 \% \mathrm{Cl})\end{array}$ \\
\hline Age in years & & \\
\hline $10-17$ & $27.2(24.9-29.4)$ & $61.6(59.8-63.3)$ \\
\hline $18-44$ & $22.2(21.1-23.4)$ & $66.7(65.3-68.0)$ \\
\hline $45-60$ & $26.7(25.2-28.2)$ & $77.6(76.1-79.0)$ \\
\hline$>60$ & $26.3(24.3-28.3)$ & $76.7(74.6-78.7)$ \\
\hline Sex & & $65.8(64.4-67.1)$ \\
\hline Male & $23.2(22.1-24.5)$ & $69.2(67.9-70.5)$ \\
\hline Female & $24.9(23.7-26.3)$ & \\
\hline Others & & \\
\hline Residence & & \\
\hline Rural & & $66.7(65.4-68.1)$ \\
\hline Urban non-slum & $21.4(20.3-22.6)$ & $69.1(66.6-71.6)$ \\
\hline Urban Slum & $29.5(27.0-32.1)$ & $71.0(66.8-74.7)$ \\
\hline
\end{tabular}

